\title{
REVIEW
}

\section{Nuclear receptors as therapeutic targets in cholestatic liver diseases}

\author{
Gernot Zollner and Michael Trauner
}

\begin{abstract}
Laboratory of Experimental and Molecular Hepatology, Division of Gastroenterology and Hepatology, Department of Internal Medicine, Medical University of Graz, Graz, Austria
\end{abstract}

\begin{abstract}
Cholestasis results in intrahepatic accumulation of cytotoxic bile acids, which cause liver damage ultimately leading to biliary fibrosis and cirrhosis. Cholestatic liver injury is counteracted by a variety of adaptive hepatoprotective mechanisms including alterations in bile acid transport, synthesis and detoxification. The underlying molecular mechanisms are mediated mainly at a transcriptional level via a complex network involving nuclear receptors including the farnesoid X receptor, pregnane $\mathrm{X}$ receptor, vitamin D receptor and constitutive androstane receptor, which target overlapping, although not identical, sets of genes. Because the intrinsic adaptive response to bile acids cannot fully prevent liver injury in cholestasis, therapeutic targeting of these receptors via specific and potent agonists may further enhance the hepatic defence against toxic bile acids. Activation of these receptors results in repression of bile acid synthesis, induction of phases I and II bile acid hydroxylation and conjugation and stimulation of alternative bile acid export while limiting hepatocellular bile acid import. Furthermore, the use of nuclear receptor ligands may not only influence bile acid transport and metabolism but may also directly target hepatic fibrogenesis and inflammation. Many drugs already used to treat cholestasis and its complications such as pruritus (e.g. ursodeoxycholic acid, rifampicin, fibrates) may act via activation of nuclear receptors. More specific and potent nuclear receptor ligands are currently being developed. This article will review the current knowledge on nuclear receptors and their potential role in the treatment of cholestatic liver diseases.
\end{abstract}

British Journal of Pharmacology (2009) 156, 7-27; doi:10.1111/j.1476-5381.2008.00030.x

Keywords: nuclear receptors; cholestasis; bile acids; bilirubin; statins; fibrates; glitazones; primary biliary cirrhosis; primary sclerosing cholangitis; obstructive cholestasis; fibrosis

Abbreviations: ASBT/Asbt (SLC10A2/S/C10a2), apical sodium-dependent bile acid transporter; BSEP/Bsep (ABCB1 1/AbCb11), bile salt export pump; CA, cholic acid; CAR (NR1I3), constitutive androstane receptor; CDCA, chenodeoxycholic acid; CYP, cytochrome P450 enzyme; CYP27A1/Cyp27a1, sterol 27-hydroxylase; CYP7A1/Cyp7a1, cholesterol 7alpha-hydroxylase; CYP8B1/Cyp8b1, sterol 12alpha hydroxylase; DCA, deoxycholic acid; FTF (NR5A2), fetoprotein transcription factor; FXR (NR1H4), farnesoid X receptor; GR (NR3C1), glucocorticoid receptor; HNF1 $\alpha$, (TCF1); hepatocyte nuclear factor 1 alpha, HNF4 $\alpha$; (NR2A1), hepatocyte nuclear factor 4 alpha; LCA, lithocholic acid; LRH1 (NR5A2), liver receptor homologue; Mdr2 (Abcb4), multidrug resistance gene 2; MDR3 (ABCB4), human homologue to rodent Mdr2; MRP/Mrp ( $A B C C / A b c c)$, multidrug resistanceassociated protein; NCoR, nuclear receptor corepressor; NR, nuclear receptor; NTCP/Ntcp (SLC10A1/SIC10a1), $\mathrm{Na}^{+}$/taurocholate cotransporter; OATP/Oatp (SLCO/S/CO), organic anion transporting peptide; OST $\alpha / O S T \beta /$ Ost $\alpha /$ Ost $\beta$, organic solute transporter alpha/beta; PFIC, progressive familial intrahepatic cholestasis; PGC1, proliferator-activated receptor-gamma coactivator-1; PPAR $\alpha$ (NR1C1), peroxisome proliferator-activated receptor alpha; PXR (NR112), pregnane X receptor; RAR $\alpha$ (NR1B1), retinoic acid receptor alpha; $R X R \alpha$ (NR2B1), retinoid X receptor alpha; SHP (NROB2), short heterodimer partner; SMRT, silent mediator of retinoic acid receptor and thyroid receptor; SULT2A1, dehydroepiandrosterone sulfotransferase; UDCA, ursodeoxycholic acid; UGT, UDP-glucuronosyl transferase; VDR (NR1I1), vitamin D receptor

Correspondence: Michael Trauner, Professor of Medicine and Molecular Hepatology, Laboratory of Experimental and Molecular Hepatology, Division of Gastroenterology and Hepatology, Department of Internal Medicine, Medical University of Graz, Auenbruggerplatz 15, A-8036 Graz, Austria. E-mail: michael.trauner@meduni-graz.at

Please note that human genes and their products are capitalized, whereas rodent genes and their products are written in lower case. Transporter genes are set in italic whereas gene products are set in normal font.

Received 12 May 2008; revised 12 August 2008; accepted 29 August 2008

\section{Introduction}

Cholestasis is defined as a disturbance of bile secretion that can result from a functional defect in bile formation at the level of hepatocytes or from impaired bile secretion and flow at the bile duct level (Trauner et al., 1998; Trauner and Boyer, 2003). Cholestasis results in the retention of substances normally secreted into bile. Retention of these cholephiles 
(particularly bile acids that are cytotoxic at high concentrations) can lead to chronic liver disease with development of biliary fibrosis, cirrhosis and ultimately end-stage liver disease requiring liver transplantation. So far, ursodeoxycholic acid (UDCA) is one of the few widely used drugs in the treatment of chronic cholestatic disorders such as primary biliary cirrhosis (PBC) and primary sclerosing cholangitis (PSC). However, the effectiveness of UDCA in PBC has been questioned by several meta-analyses, and UDCA delays disease progression only when initiated at early stages (Paumgartner and Pusl, 2008). UDCA improves liver tests in patients with PSC, but its effects on survival remain also unclear (Cullen and Chapman, 2006). Therefore future research is needed to develop novel and more effective drugs for cholestatic diseases. Nuclear receptors (NRs) are promising therapeutic targets for cholestatic liver diseases.

\section{Principal therapeutic targets in cholestasis}

Because cholestasis can be defined from a pathophysiological perspective as a reduction in bile secretion leading to retention of substances normally secreted into bile, at a first glance, restoration of bile flow might be considered a primary therapeutic target (Fig. 1). However, it has to be kept in mind that a mere increase of bile flow in obstructive cholestasis without resolution of the cause may worsen the disease course due to increase of biliary pressure leading to rupture of cholangioles and to the development of bile infarcts. This has been observed in bile duct-ligated mice and in a mouse model of sclerosing cholangitis after administration of UDCA at choleretic doses (Fickert et al., 2002). Many relevant human cholestatic disorders, which are primarily not considered to be obstructive, may have obstructive components to various extents. Potential examples include PSC, secondary sclerosing cholangitis and late stage $\mathrm{PBC}$ with pronounced ductopenia.

Which mechanisms should be targeted by novel therapeutic strategies? A major aim of therapy may be to reduce accumulation of toxic biliary constituents such as bile acids. This can be achieved by reducing basolateral hepatic uptake and by increasing hepatocellular excretion of these compounds (Fig. 1). As mentioned above, canalicular secretion should be kept low in order to prevent an increase in biliary pressure in obstructive forms of cholestasis. Stimulating alternative basolateral secretion of water soluble compounds into sinusoidal blood is expected to enhance renal elimination of accumulating substances in cholestasis (Fig. 1). Increasing water solubility and reducing toxicity can be achieved by phase I and phase II detoxification reactions (Fig. 1). In addition, repression of bile acid synthesis will also reduce bile acid accumulation (Fig. 1). Another strategy is to reduce toxicity of bile by increasing the biliary phospholipid content. This may be relevant under conditions with stagnant or low bile flow and increased exposure of cholangiocytes to toxic biliary constituents. Because long-term cholestasis leads to the development of biliary cirrhosis, direct inhibition of fibrosis may also be an attractive strategy (Fig. 1).

Bile acid homeostasis is regulated to large extent at a transcriptional level via NRs that play a key role in the regula-

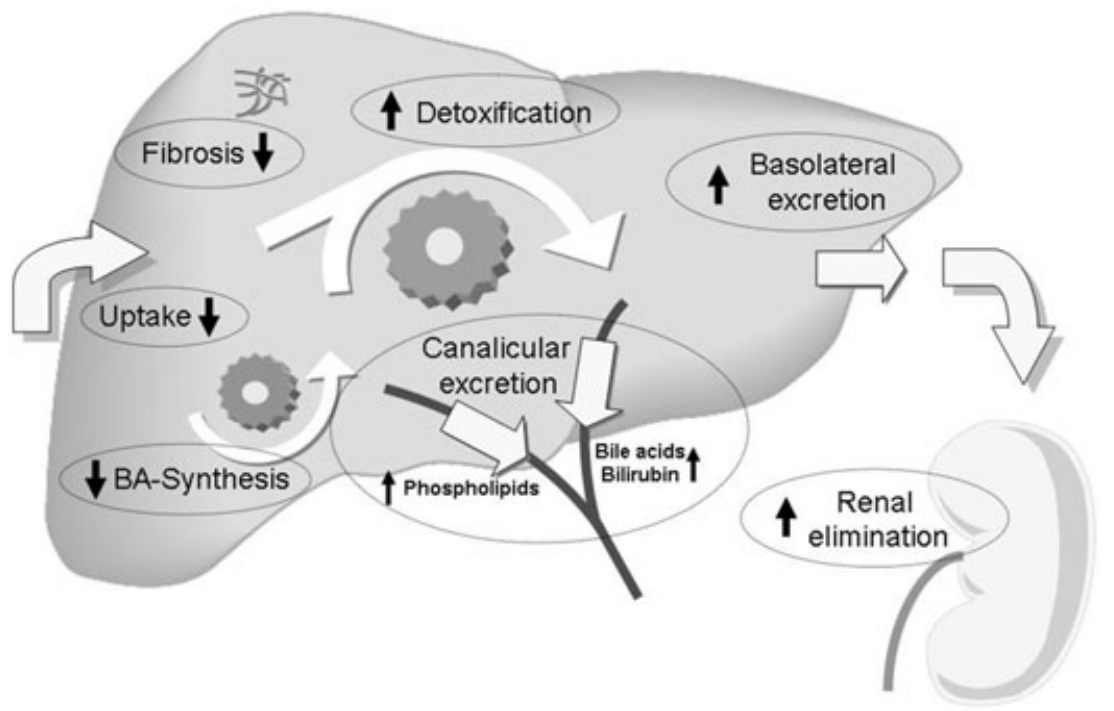

Figure 1 Targets for nuclear receptor ligands in cholestasis. Therapeutic approaches in cholestasis should primarily aim at limiting accumulation of toxic biliary constituents (especially bile acids, BA). This can be achieved by reducing basolateral hepatic uptake and by increasing orthograde canalicular and retrograde (alternative) basolateral secretion. Increasing canalicular secretion will also lead to an increase in bile flow, which might be beneficial in some (early and primarily canalicular) forms of cholestasis. In obstructive cholestasis, however, an increase in bile flow will lead to an increase in biliary pressure with subsequent rupture of cholangioles and liver injury. Stimulating alternative basolateral secretion of water soluble compounds into sinusoidal blood is followed by increased renal elimination of these substances. Increasing water solubility and reducing toxicity can be achieved by phase I and phase II detoxification reactions that also facilitate renal elimination due to reduced albumin binding. In addition, repression of bile acid synthesis will also reduce bile acid accumulation. Other therapeutic strategies in cholestasis include reduction of the toxicity of bile by increasing the biliary phospholipids content and direct inhibition of fibrosis. All these protective mechanisms are regulated to a large extent at a transcriptional level by nuclear receptors. Therapeutic administration of nuclear receptor ligands can activate these defence pathways. Adapted from SJ Karpen, Hepatology 2005 (Karpen, 2005). 
tion of hepatobiliary transport systems, bile acid synthesis and of enzymes involved in bile acid detoxification (Karpen, 2002; Eloranta and Kullak-Ublick, 2005; Zollner et al., 2006b). NRs comprise a family of transcription factors that regulate gene expression in a ligand-dependent manner. All NRs share several structural domains that are essential for receptor function (Kumar et al., 2004). The carboxy-terminal region includes the ligand-binding domain, dimerization interface and a ligand-dependent activation function (Chawla et al., 2001). Upon ligand binding, NRs undergo a conformational change that coordinately dissociates corepressors and facilitates recruitment of coactivator proteins to enable transcriptional activation (McKenna et al., 1999). The NR ligand-binding domain is connected to the DNA-binding domain by a short flexible linker and mediates liganddependent transactivation functions (Glass and Rosenfeld, 2000). The DNA-binding domain is highly conserved and contains two $\alpha$ helices and two zinc fingers that are involved in the specificity of response-element recognition and in receptor dimerization (Staudinger, 2008). Most NRs bind to their DNA response elements in a sequence-specific manner as dimers, functioning either as homodimers or as heterodimers with the retinoid X receptor (RXR) (Mangelsdorf and Evans, 1995). The N-terminal region is highly variable but always contains a region called activation function 1 with many phosphorylation sites (Staudinger, 2008). Increasing knowledge on the three-dimensional structure of NRs (e.g. through crystallization studies) has facilitated the design of small molecules specifically targeting their ligand-binding domain (Pellicciari et al., 2005; Westin et al., 2005).

The precise regulation of transcription by NRs requires the recruitment of intermediary factors characterized as coregulators. These factors modulate transcriptional initiation at regulated promoters by modifying chromatin structures and assembling transcriptional initiation complexes. These coregulators can have positive and negative actions on target gene expression. Coregulator proteins modulate the transcription of NR target genes by participating in chromatin remodelling or interacting with general transcription machinery to affect the formation of the preinitiation complex (Perissi and Rosenfeld, 2005). Coactivators such as peroxisome proliferator-activated receptor-gamma coactivator-1 (PGC-1) promote NR-transcriptional activation in the presence of NR ligands while corepressors such as nuclear receptor corepressor (NCoR) and silent mediator of retinoic acid receptor and thyroid receptor (SMRT) mediate NR-dependent transcriptional silencing in absence of ligands (Nishihara et al., 2004).

Because NRs are the central regulators of bile acid synthesis, transport and detoxification and also play a role in modulating fibrosis, specific targeting of NRs represents an innovative approach for the treatment of cholestasis. Extensive research in the field of cholestasis has provided a detailed understanding of the molecular mechanisms involved in bile formation, bile acid homeostasis and NR function under physiological and pathological conditions over the last decade. This knowledge is required for the development of such NR-targeted therapies and will therefore be briefly reviewed.

\section{Molecular mechanisms of bile formation and cholestasis}

Bile acids are synthesized from cholesterol by a complex pathway consisting of a cascade of 16 reactions (Chiang, 1998). The cholesterol $7 \alpha$-hydroxylase (CYP7A1) initiates the first, rate limiting step in bile formation in the classical bile acid synthesis pathway finally producing cholic acid (CA) and chenodeoxycholic acid (CDCA) in equal amounts (Myant and Mitropoulos, 1977). Sterol 12alpha hydroxylase (CYP8B1) controls the ratio of CA to CDCA in this pathway. The alternative pathway is initiated by sterol 27-hydroxylase (CYP27A1) leading to the production of CDCA (Pikuleva et al., 1998). The driving force for hepatocellular bile formation is the active transport of bile acids from sinusoidal blood into the canaliculus. Specific transport proteins are localized to the basolateral (sinusoidal) and canalicular (apical) membrane of hepatocytes and cholangiocytes (Fig. 2) and have recently been reviewed elsewhere (Trauner and Boyer, 2003; Pellicoro and Faber, 2007). Defects in transporter systems can cause rare forms of inherited cholestatic syndromes leading to cholestasis already in childhood (Oude Elferink et al., 2006). Transporter defects may be also incomplete not causing any phenotype under physiologic concentrations but may become evident when the patient is challenged with a cholestatic agent (e.g. drugs, sex-hormones, cytokines released by inflammation) (Oude Elferink et al., 2006). However, in most cholestatic disorders transporter alterations may rather be the consequence than the cause of cholestasis and largely represent an attempt to adapt to accumulating biliary constituents in cholestasis and protect hepatocytes from intracellular accumulation of toxic bile acids. A complex machinery of coordinated mechanisms is activated by bile acids to counteract cholestatic liver injury (Zollner et al., 2006b). Such adaptive mechanisms include repression of basolateral bile acid uptake and bile acid synthesis, induction of bile acid detoxification systems (i.e. phase I bile acid hydroxylation and phase II conjugation with sulphate or glucuronidate) and recruitment of alternative export pumps for cholephiles at the basolateral membrane. Adaptive mechanisms in response to cholestasis are not only restricted to the hepatocytes but also observed in kidney, intestine and bile duct epithelium (Zollner and Trauner, 2006).

Limiting hepatic bile acid uptake and bile acid synthesis during cholestasis are considered as protective mechanisms to reduce hepatocellular bile acid overload. Expression of the main basolateral bile acid uptake systems, the $\mathrm{Na}^{+}$/ taurocholate cotransporter (NTCP/Ntcp) and the organic anion transporter OATP1B1/SCLO1B1 (formerly known as OATP-C or OATP2) is reduced in human cholestatic liver diseases and in rodent models of cholestasis and bile acid overload (for review see Zollner and Trauner, 2008). CYP7A1 is repressed by bile acids and by other bile acid-independent mechanisms (Chiang, 2004), and CYP7A1 is down-regulated in late stage PBC (Zollner et al., 2007).

Bile acid hydroxylation (phase I) and conjugation (phase II) renders bile acid more hydrophilic, less toxic and more amenable for urinary excretion as a result of reduced albumin binding. Phase I detoxification (hydroxylation) is mediated by CYP3A4 (and by its rodent homologue Cyp3a11) (Araya 


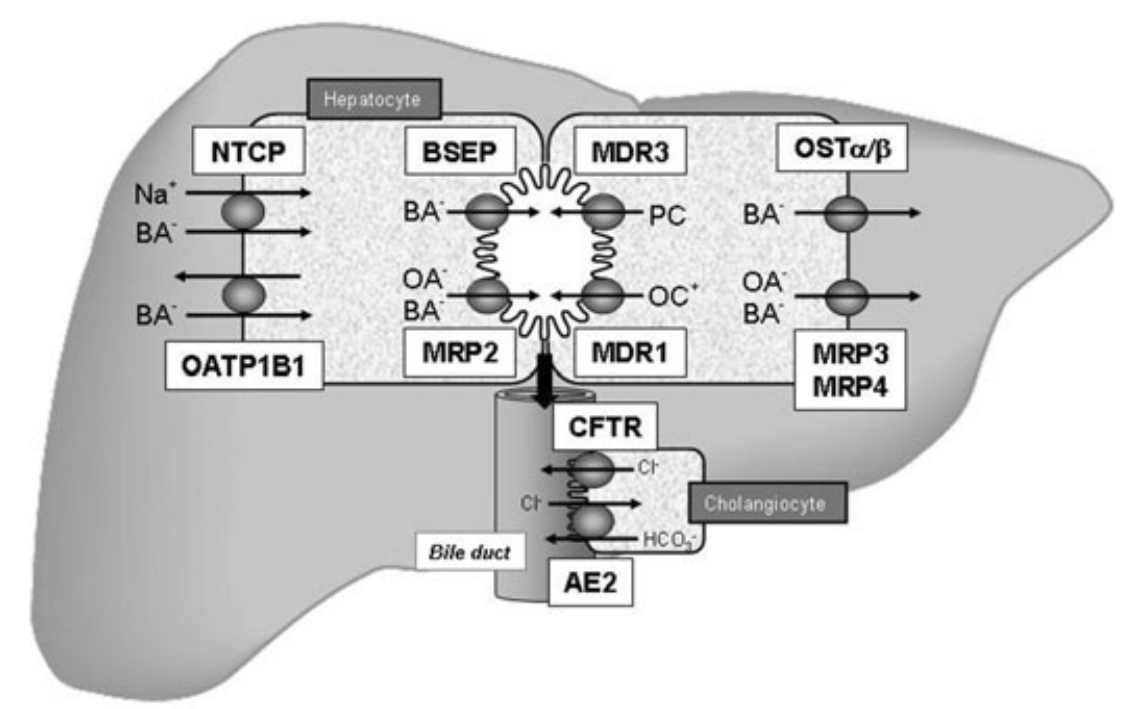

Figure 2 Hepatobiliary transport systems in the liver. Bile acids (BA ${ }^{-}$) are taken up by the $\mathrm{Na}^{+} /$taurocholate cotransporter (NTCP) and organic anion transporting protein2 (OATP2) at the basolateral membrane of hepatocytes. Monovalent BA ${ }^{-}$are excreted into bile by the canalicular bile salt export pump (BSEP), divalent BAs and anionic anions $\left(\mathrm{OA}^{-}\right)$are exported by the canalicular conjugate export pump (MRP2). The phospholipid export pump (MDR3) mediates excretion of phosphatidylcholine (PC), which forms mixed micelles together with $B^{-}$and cholesterol in bile. Cationic drugs $\left(\mathrm{OC}^{+}\right)$are excreted by the multidrug export pump (MDR1). At the basolateral membrane of hepatocytes, MRP3, MRP4 and the heteromeric organic solute transporter OST $\alpha / \beta$ provide an alternative excretion route for $\mathrm{BA}^{-}$and other $\mathrm{OA}^{-}$into the systemic circulation. $\mathrm{BA}^{-}$secreted into bile can be reabsorbed by cholangiocytes via apical $\mathrm{Na}^{+}$-dependent bile salt transporter (ASBT) and effluxed by Ost $\alpha / \beta$ and Mrp3 (not shown). Cholangiocytes also express a chloride channel that is the cystic fibrosis transmembrane regulator (CFTR) that drives bicarbonate secrtion via a chloride/anion exchanger (AE2). Adapted from Zollner and Trauner, Wien Med Wochenschr 2006 (Zollner and Trauner, 2006).

and Wikvall, 1999; Handschin and Meyer, 2003; Bodin et al., 2005). Cyp3a11 levels are increased in rodent models of obstructive cholestasis and in bile acid-challenged mice leading to increased urinary excretion of (poly-)hydroxylated bile acids (Schuetz et al., 2001; Staudinger et al., 2001b; Xie et al., 2001; Makishima et al., 2002; Stedman et al., 2004; Marschall et al., 2006; Zollner et al., 2006a). Phase II conjugation reactions of bile acids with sulphate or glucuronidate are catalysed by dehydroepiandrosterone-sulfotransferase (SULT2A1) and by the UDP-glucuronosyltransferases UGT2B4 and UGT2B7 respectively (Falany, 1997; Weinshilboum et al., 1997; Gall et al., 1999; King et al., 2000). The appearance of hydroxylated, sulphated and glucuronidated bile acids in urine of patients with cholestatic diseases indicates that these detoxification pathways are activated in human cholestatic diseases (Makino et al., 1975; Berge Henegouwen et al., 1976; Frohling and Stiehl, 1976; Alme et al., 1977; Bremmelgaard and Sjovall, 1979; 1980; Thomassen, 1979; Alme and Sjovall, 1980; Shoda et al., 1990).

Hepatocellular bile acid efflux via the basolateral membrane may become an important alternative spill-over route for accumulating bile acids during cholestasis. This alternative (or retrograde) basolateral bile acid export is mediated by the multidrug resistance-associated proteins MRP3, MRP4 and the heteromeric organic solute transporter OST $\alpha /$ OST $\beta$ (Dawson et al., 2005). These export systems are normally expressed at very low levels at the basolateral membrane but are dramatically up-regulated after bile acid feeding and in experimental cholestasis in rodents as well as in human cholestatic liver diseases (Hirohashi et al., 1998; Ogawa et al., 2000; Donner and Keppler, 2001; Fickert et al., 2001; Schuetz et al., 2001; Shoda et al., 2001; Soroka et al., 2001; Tanaka et al., 2002; Zollner et al., 2003a,b; 2006c; 2007; Keitel et al., 2005). The substrate specificity of MRP3, MRP4 and OST $\alpha /$ OST $\beta$ includes phase II conjugation products suggesting an interplay between detoxification and subsequent basolateral export systems. Bile acids reaching the systemic circulation are filtered at the glomerulus from plasma into urine thus establishing an alternative way for their excretion (Wilson et al., 1981).

The data derived from animal models of cholestasis and human cholestatic diseases indicate that adaptive mechanisms aimed at counteracting liver injury are intrinsically activated in cholestasis. However, these protective mechanisms do not suffice to completely avoid liver damage. Thus additional targeting these pathways via key regulatory NRs appears as an innovate approach (Fig. 3). This will be the focus of this review.

\section{Farnesoid X receptor [FXR (NR1H4)] and short heterodimer partner [SHP (NROB2)]}

FXR is a major intracellular bile acid receptor that regulates the expression of a wide variety of genes involved in bile acid synthesis, metabolism and transport (Fig. 3, Table 1). FXR binds to its response element generally as a heterodimer with retinoid X receptor RXR (NR2B1). The preferred DNA-binding motifs are inverted repeat elements separated by one nucleotide [inverse repeat (IR)-1] (Laffitte et al., 2000). Physiologic ligands for FXR are CDCA, deoxycholic acid (DCA), lithocholic acid (LCA) and CA (Parks et al., 1999). In addition to bile acid homeostasis, FXR also regulates triglyceride, cholesterol and glucose metabolism (Lee et al., 2006a). Moreover, FXR has been shown to modulate liver regeneration, carcinogenesis, inflammation, bacterial overgrowth in the intestine 


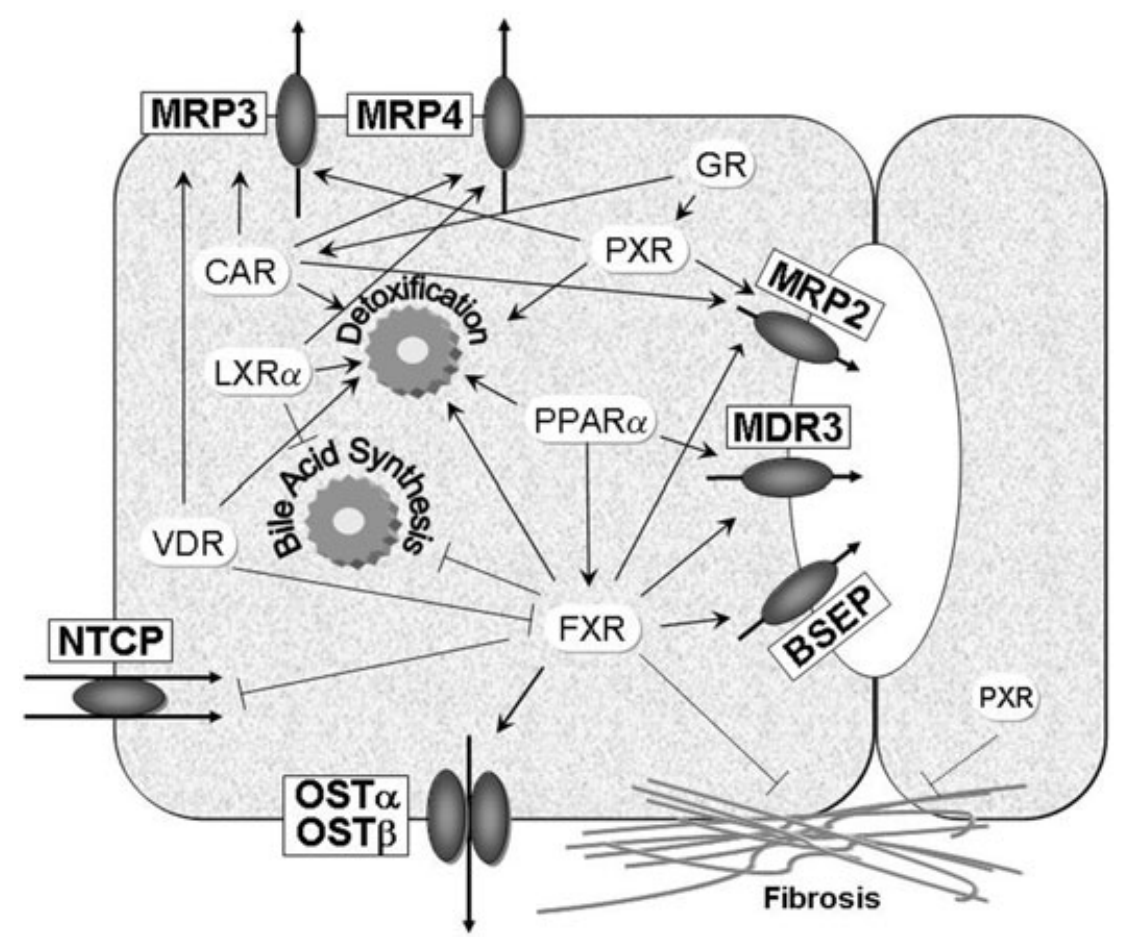

Figure 3 Nuclear receptors as therapeutic targets in cholestasis. Nuclear receptors regulate a large number of target genes mediating transport, synthesis and detoxification of biliary constituents including bile acids. This figure summarizes the anti-cholestatic properties of nuclear receptors that can be targeted therapeutically by synthetic and natural ligands. As indicated in the figure, nuclear receptors regulate overlapping sets of target genes. This may be of relevance, when expression of one nuclear receptor is low due to disease state (as observed in cholestasis). In addition, nuclear receptors may directly regulate fibrogenesis Arrows indicate stimulatory effects, the other lines indicate suppressive effects on target genes. BSEP, bile salt export pump; CAR, constitutive androgen receptor; FXR, farnesoid X receptor; GR, glucocorticoid receptor; LXR, liver X receptor; MRP, multidrug resistance-associated protein; NTCP, $\mathrm{Na}^{+} /$taurocholate cotransporter; OST, organic solute transporter; PPAR, peroxisome proliferator-activated receptor; PXR, pregnane X receptor; VDR, vitamin D receptor.

and hepatitis $\mathrm{C}$ virus replication making it a very attractive target for hepatobiliary and gastrointestinal disorders (Huang et al., 2006; Inagaki et al., 2006; Kim et al., 2007c; Yang et al., 2007; Scholtes et al., 2008).

Bile acid synthesis

FXR plays a central role in regulation of bile acid synthesis. Bile acid-activated FXR represses CYP7A1 gene transcription by induction of the nuclear repressor SHP. SHP was suggested to negatively interact with fetoprotein transcription factor (FTF/NR5A1, also known as liver receptor homologue, LRH-1), which binds to the bile acid response element (BARE) located within the proximal CYP7A1 promoter region together with hepatocyte nuclear factor (HNF) $4 \alpha$ (Stroup et al., 1997; Chiang et al., 2000; Goodwin et al., 2000; Lu et al., 2000). A similar mechanism has been proposed for regulation of Cyp8b1 (Castillo-Olivares and Gil, 2000; Goodwin et al., 2000; Zhang and Chiang, 2001). However, recent studies indicate that LRH-1 is not involved in feedback regulation of either Cyp7a1 or Cyp $8 b 1$ because LRH-1 deficiency in hepatocytes has no significant effects on FXR-mediated repression of these genes (Lee et al., 2008). An additional gut-liver signalling pathway in the regulation of bile acid homeostasis is mediated via fibroblast growth factor Fgf15 (the rodent homologue of human FGF19). Bile acids induce intestinal Fgf15 expression in an FXR-dependent fasion in mice. Fgf15 signals from intestine to the liver to repress Cyp7a1 through a mechanism involving Fgf receptor 4 (FgfR4) and a c-Jun N-terminal kinase (JNK)-dependent pathway (Holt et al., 2003; Inagaki et al., 2005). The role of this intestinal FXR/Fgf-15 pathway has recently been confirmed in intestine-specific FXR knockout mice (Kim et al., 2007b). In this study, the FXR agonist GW4064 repressed Cyp7a1 only in intestine- but not in liverspecific FXR-deficient animals. In contrast, Cyp8b1 repression by the synthetic FXR ligand GW4064 was more dependent on the presence of FXR in liver than in intestine indicating mechanistic differences in feedback repression of Cyp7a1 and Cyp8b1 (Kim et al., 2007b). In addition to FXR/SHP, multiple redundant pathways regulate expression of bile acid synthesis enzymes. Bile acids can also directly block recruitment of the transcriptional coactivator PGC-1, which is bound to HNF4 $\alpha$ thereby abolishing the activating effects of HNF4 $\alpha$ (De Fabiani et al., 2003). A detailed review of these redundant pathways is given elsewhere (Chiang, 2004; Eloranta and Kullak-Ublick, 2005; Zollner et al., 2006b).

\section{Bile acid uptake}

FXR negatively regulates the main bile acid uptake system Ntcp via SHP. Bile acid-activated FXR induces expression of SHP, which in turn interferes with RXR $\alpha$ : RAR $\alpha$ (retinoic acid receptor $\alpha$ ) mediated activation of the rat Ntcp promoter (Denson et al., 2001). In addition, SHP reduces Ntcp expres- 
Table 1. Nuclear receptors as therapeutic targets in cholestasis

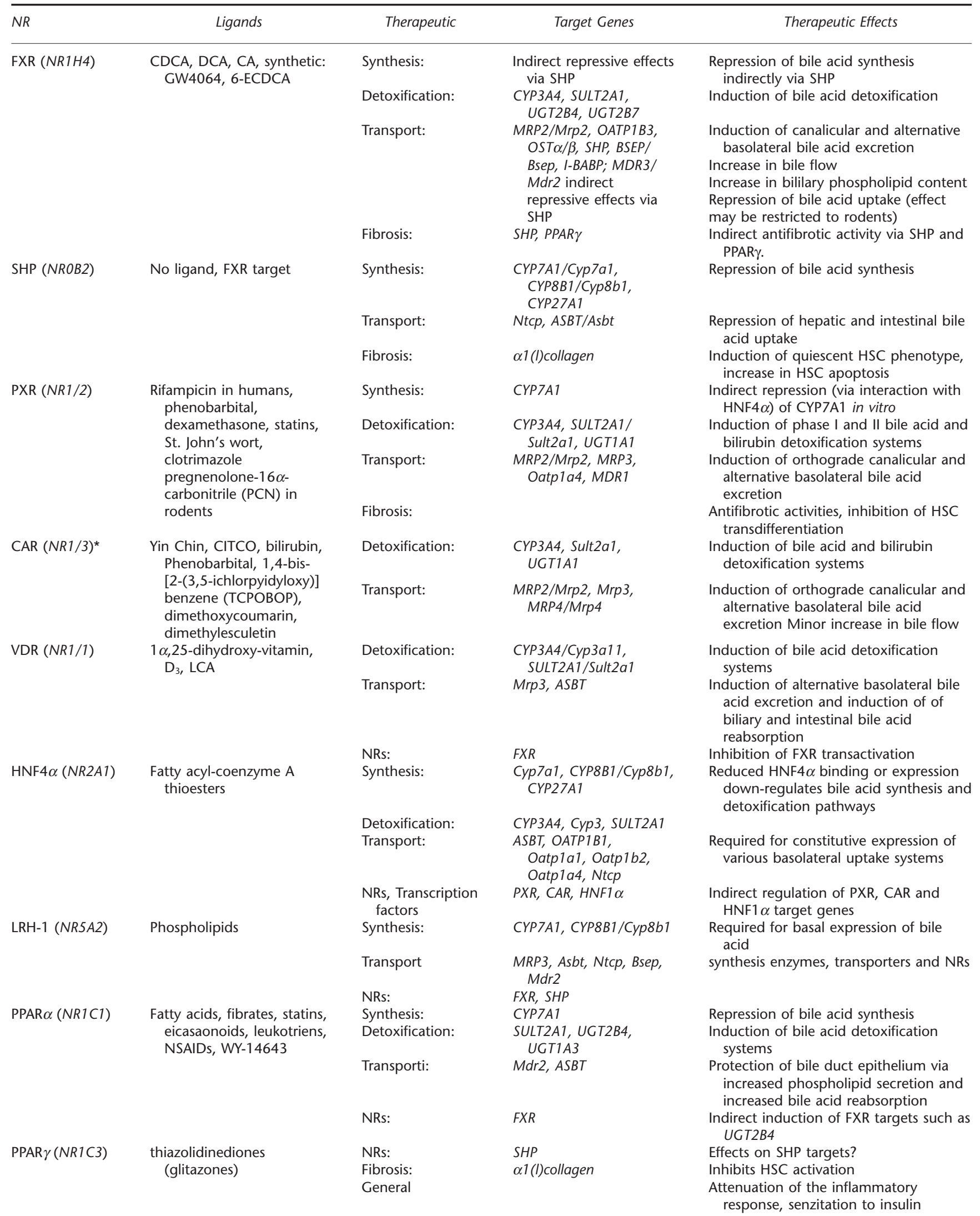


Table 1. Cont.

\begin{tabular}{|c|c|c|c|c|}
\hline$N R$ & Ligands & Therapeutic & Target Genes & Therapeutic Effects \\
\hline \multirow[t]{3}{*}{$\mathrm{LXR} \alpha(\mathrm{NR} 1 \mathrm{H} 3)$} & $\begin{array}{l}\text { Oxysterols, fatty acids, } \\
6 \alpha \text {-hydroxylated bile }\end{array}$ & Synthesis: & Сур7a1/CYP7A1 & $\begin{array}{l}\text { Induction of rodent Cyp7a1, repression } \\
\text { of human CYP7A1 }\end{array}$ \\
\hline & acids, TO1317 & Detoxification: & Sult2a9, UGT1A3 & $\begin{array}{l}\text { Induction of bile acid sulfation and } \\
\text { glucuronidation }\end{array}$ \\
\hline & & Transport: & Mrp4 & $\begin{array}{l}\text { Induction of alternative basolateral bile } \\
\text { acid excretion }\end{array}$ \\
\hline \multirow[t]{2}{*}{$\mathrm{GR}(\mathrm{NR} 3 \mathrm{C} 1)$} & $\begin{array}{l}\text { Glucocorticoids, potentially } \\
\text { UDCA }\end{array}$ & Transport: & $\begin{array}{l}A S B T, N T C P \text {, potentially } \\
\text { AE2, Bsep, Mrp2 }\end{array}$ & $\begin{array}{l}\text { Contribution of effects on transporters } \\
\text { to anti-inflammatory properties in } \\
\text { treatement of inflammatory } \\
\text { cholestasis ("steroid whitewash") }\end{array}$ \\
\hline & & NRs: & $C A R, P X R, R X R \alpha$ & Potentiates action of PXR and CAR \\
\hline
\end{tabular}

*Please note that CAR can be activated either indirectly or directly by ligand binding (e.g. TCPOBOP (Goodwin et al. 2004).

sion via a complex pathway involving repression of $\mathrm{HNF} 4 \alpha$ and HNF1 $\alpha$, the latter being an essential Ntcp transactivator (Karpen et al., 1996; Lee et al., 2000; Jung and Kullak-Ublick, 2003). While the role of SHP in NTCP/Ntcp regulation has been questioned (Wang et al., 2002; Jung et al., 2004b), data obtained in CA-fed and bile duct-ligated FXR knockout mice indicate an important role for FXR in Ntcp regulation by bile acids (Zollner et al., 2005). In contrast, the human NTCP promoter does not contain the rat RXR $\alpha$ : RAR $\alpha$ and $H N F 4 \alpha$ response elements (Jung et al., 2004b). Reduced NTCP expression in various human cholestatic diseases (Shoda et al., 2001; Zollner et al., 2001; 2003b) might be explained by suppression of glucocorticoid receptor (GR)-mediated activation of human NTCP by FXR/SHP (Eloranta et al., 2006). Additional FXR/SHP independent pathways in bile acid-mediated Ntcp regulation also play an important role (Li et al., 2002; Wang et al., 2002; Zollner et al., 2006b).

Bile acid detoxification

In addition to the pregnane $\mathrm{X}$ receptor (PXR) and the constitutive androgen receptor (CAR) as the central regulators of phases I and II enzymes, FXR is also involved in controlling bile acid detoxification pathways. FXR positively regulates human CYP3A4 (Gnerre et al., 2004), while it is not required for up-regulation of mouse orthologue Cyp3a11 (Schuetz et al., 2001; Marschall et al., 2006; Zollner et al., 2006a). On the contrary, FXR-deficient bile duct-ligated mice even have higher levels of Cyp3a11 and increased bile acid hydroxylation rates indicating species differences (Marschall et al., 2006) and that other NRs such as PXR may take over when FXR is absent. FXR also positively regulates SULT2A1 by binding to an IR-0 response element in its gene promoter (Song et al., 2001). Bile acids can induce human UGT2B4 via activation of FXR (Barbier et al., 2003b). Of note, UGT2B4 is the only gene described so far to be activated by FXR through binding of an FXR monomer to a single hexameric DNA motif without its common heterodimeric partner RXR.

Bile acid efflux

While most of FXR's repressive effects are indirect and largely mediated by the activation of SHP, bile salt export pump (BSEP) is directly transactivated by FXR. (Ananthanarayanan et al.,
2001; Gerloff et al., 2002; Plass et al., 2002). Bile acids increase BSEP expression in primary human hepatocytes or HepG2 cells with the same rank order of potency that activates FXR (Schuetz et al., 2001). In addition, MRP2 is also induced by FXR ligands (Kast et al., 2002). The human phospholipid export pump MDR3 contains an FXR response element in its gene promoter, and expression is stimulated by the natural and synthetic FXR ligands CDCA and GW4046 respectively (Huang et al., 2003a). Murine Mdr2 (the rodent homologue to human MDR3) expression is lower in FXR-deficient mice, and Mdr2 induction by GW4064 is abolished in these animals (Moschetta et al., 2004). Thus, bile acids not only induce their own efflux into bile by increasing BSEP expression but also stimulate phospholipid secretion, which is needed to maintain the bile acid/lipid ratio in bile to prevent bile duct injury by non-micellar bound bile acids. When orthograde biliary bile acid output is reduced, retrograde bile acid secretion represents an alternative elimination route to reduce accumulation of toxic bile acids within hepatocytes. Bile acid-activated FXR transactivates the basolateral efflux system Ost $\alpha /$ Ost $\beta$. Two functional FXR-binding motifs were identified in the human OST $\alpha$ gene, and one in the OST $\beta$ gene indicating a role of FXR in modulation of alternative bile acid secretory pathways (Landrier et al., 2006; Lee et al., 2006b).

\section{FXR and fibrosis}

FXR also plays a role in regulation of hepatic stellate cells (HSCs), which are the major source for extracellular matrix deposition in the liver. Activation of FXR by the synthetic CDCA derivate 6-ethyl chenodeoxycholic acid (6-ECDCA), reduces liver fibrosis in a rat model of bile duct obstruction and reduces human and rat HSC transdifferentiation (Fiorucci et al., 2004; 2005b,c). The antifibrotic properties of FXR are mediated via SHP and the peroxisome proliferator-activated receptor (PPAR) $\gamma$. SHP reduces $\alpha 1$ (I) collagen mRNA by interfering with activator protein 1 (AP1), promotes the development of a quiescent HSC phenotype and increases apoptosis of HSCs (Fiorucci et al., 2004; 2005c). FXR induces PPAR $\gamma$ expression, which also leads to down-regulation of $\alpha 1$ (I) collagen mRNA expression and to counter-regulation of HSC activation in rodent models of fibrosis (including obstructive cholestasis) (Fiorucci et al., 2005b). However, these data have to be validated in further studies. 
Table 2 Nuclear receptor ligands currently tested in clinical trials for cholestasis

\begin{tabular}{llll}
\hline Drug & Nuclear receptor target & Cholestatic disorder & ClinicalTrials. gov weblink \\
\hline INT-747 (6-ECDCA) & FXR & PBC/monotherapy & http://clinicaltrials.gov/ct2/show/NCT00570765 \\
INT-747 (6-ECDCA) & FXR & PBC/combination therapy with UDCA & http://clinicaltrials.gov/ct2/show/NCT00550862 \\
Fenofibrate & PPAR $\alpha$ & PBC & http://clinicaltrials.gov/ct2/show/NCT00575042 \\
\hline
\end{tabular}

6-ECDCA, 6-ethyl chenodeoxycholic acid; FXR, farnesoid X receptor; PBC, primary biliary cirrhosis; PPAR, peroxisome proliferator-activated receptor.

\section{Therapeutic targeting of FXR}

Taken together, FXR is critically involved in the regulation of bile acid transport, synthesis and metabolism, of biliary phospholipid secretion and may also play a role in modulation of HSC activity (Table 1). This makes FXR a highly interesting target for drug therapy. Further data suggesting that stimulation of FXR would be an ideal therapeutic approach in cholestasis include: (i) low FXR expression and activity in cholestasis (especially in inflammatory cholestasis) (Kim et al., 2003); (ii) increased liver injury in FXR-deficient mice upon bile acid challenge (Sinal et al., 2000; Zollner et al., 2003a); and (iii) the association of low expression of FXR and FXR target genes (i.e. BSEP) with various human cholestatic disorders (i.e. progressive intrahepatic cholestasis, intrahepatic cholestasis of pregnancy) (Strautnieks et al., 1998; Chen et al., 2004; Van Mil et al., 2007).

Indeed, beneficial effects of pharmacologic FXR activation have been observed in oestrogen-induced cholestasis in rodents. Administration of the synthetic FXR ligands 6ECDCA and GW4064 to oestrogen-treated rats restored bile flow and reduced serum markers of cholestasis. This was attributed to repression of basolateral bile acid uptake and bile acid synthesis and to induction of canalicular transporters (Fiorucci et al., 2005a). Reduced transporter function may be causative in oestrogen-induced cholestasis (Kullak-Ublick et al., 2000), and stimulation of reduced transport function may indeed be beneficial. This may be true for other forms of cholestasis where transporter defects are suspected to contribute to cholestasis (e.g. hereditary cholestatic diseases such as progressive familial intrahepatic cholestasis, sepsis-associated cholestasis and intrahepatic cholestasis of pregnancy). Most clinically relevant cholestatic disorders, however, are the consequence of bile duct obstruction (e.g. large bile duct obstruction by stones or tumours, small bile duct obstruction as observed in PSC) or bile duct loss (i.e. vanishing bile duct syndromes like late stage $\mathrm{PBC}$ ). In these diseases, alterations of transporter expression and function are not causing cholestasis but rather are secondary events as a consequence of bile acid retention (Zollner and Trauner, 2006). Especially in obstructive cholestasis, stimulation of biliary bile flow may be detrimental. Stimulation of bile flow even with the hydrophilic bile acid UDCA in a mouse model of sclerosing cholangitis and in bile duct ligated mice increased liver injury, aggravated bile infarcts and induced hepatocyte necroses (Fickert et al., 2002). Increased liver injury is caused by increased biliary pressure due to UDCA's choleretic activity leading to rupture of cholangioles (Fickert et al., 2002). Moreover, the central role for FXR in worsening cholestatic injury in obstructive cholestasis was confirmed in bile duct-ligated and UDCA-fed FXR-deficient mice, which are protected from cholestasis and lack the development of bile infarcts (Wagner et al., 2003; Stedman et al., 2006). Serum bile acid levels in bile duct-ligated mice lacking FXR were even lower, and urinary bile acid output was increased, indicating enhanced adaptation to cholestasis in FXR-deficient mice (Marschall et al., 2006). Some of UDCA's effects can be attributed to activation of FXR because UDCA is a weak FXR ligand (Lew et al., 2004). UDCA may also exert FXR antagonistic properties by changing the bile acid pool composition and reducing the relative amounts of stronger FXR ligands like CDCA and CA. However, most of UDCA's negative effects in biliary obstruction are probably due to inducing choleresis and not to activation or inactivation of FXR.

Taken together, FXR agonists should be used with caution in human cholestasis with an obstructive component or with bile duct loss (e.g PSC, late stage PBC). Whether these substances are of benefit when initiated early in the course of vanishing bile duct syndromes, is currently tested in ongoing clinical studies. As such, a clinical phase II study is addressing the effects of 6-ECDCA in PBC patients, but results are still pending (Table 2). Moreover, future studies will have to differentiate between potential direct hepatic versus indirect intestinal (e.g. FGF-mediated) therapeutic effects of FXR agonists.

\section{PXR (NR1I2) and CAR (NR1I3)}

PXR and CAR are master regulators of phases I and II detoxification and regulate numerous hepatic genes in response to a large group of xenobiotics and endobiotics (Fig. 3, Table 1). These two receptors share some common ligands and regulate an overlapping set of target genes. CAR and PXR form heterodimers with RXR. PXR and CAR reside in the cytoplasm and are translocated to the nucleus after ligand binding (Goodwin and Moore, 2004; Squires et al., 2004; Moreau et al., 2008). PXR is activated by a broad range of xenobiotics but also by LCA (Staudinger et al., 2001b; Xie et al., 2001; Tirona and Kim, 2005). CAR is activated by xenobiotics but has also been shown to be activated by bilirubin, and a role of CAR for sensing bile acids has been suggested (Guo et al., 2003; Huang et al., 2003b; Xie et al., 2004; Tirona and Kim, 2005).

\section{Bile acid detoxification}

Phase I hydroxylation of endobiotic and xenobiotic is largely mediated by CYP3A4. Both PXR and CAR are key regulators of CYP3A4 expression in hepatocytes and ligands for these receptors including xenobiotics, drugs but also bile acids can induce CYP3A4 expression (Bertilsson et al., 1998; Lehmann 
et al., 1998; Staudinger et al., 2001a,b; Xie et al., 2001; Goodwin et al., 2002a,b). The importance of PXR in defence to toxic bile acids is underlined in LCA-fed PXR-deficient mice. While Cyp3a11 is induced after LCA feeding in wild type mice, Cyp3a11 induction is absent in PXR knockout mice leading to increased liver injury (Staudinger et al., 2001b; Xie et al., 2001). The human CAR response elements also mediates transactivation of CYP3A4 by human PXR, suggesting that interplay between these receptors is likely to be an important determinant of CYP3A4 expression (Goodwin et al., 2002b).

Phase II bile acid sulphation via SULT2A1/Sult2a1 is regulated by numerous NRs including PXR, CAR, FXR and vitamin D receptor (VDR) (Runge-Morris et al., 1999; Song et al., 2001; Sonoda et al., 2002; Assem et al., 2004; Echchgadda et al., 2004; Saini et al., 2004; Echchgadda et al., 2007). PXR, CAR and FXR bind to the same IR-0 element within the rodent Sult2a1 gene promoter (Runge-Morris et al., 1999; Song et al., 2001; Sonoda et al., 2002; Assem et al., 2004; Saini et al., 2004). CAR appears to be the central regulator of bile acid sulphation because CAR transgenic mice are resistant against LCA toxicity due to increased LCA sulphation (Saini et al., 2004). Furthermore, CAR is required to up-regulate basolateral Mrp4, which is able to transport steroid sulphate conjugates (Assem et al., 2004). Thus, CAR coordinates an integrated pathway mediating bile acid sulphation and subsequent basolateral export. Besides hydroxylation and sulphation, PXR and CAR also control glutathione S-transferases and UGTs (Falkner et al., 2001; Huang et al., 2003b; Xie et al., 2003; Gong et al., 2006).

Bile acid synthesis

In vitro studies suggested that PXR also inhibits human CYP7A1 gene transcription by reducing interaction of peroxisome PGC- $1 \alpha$ with HNF4 $\alpha$ leading to inhibition of human CYP7A1 gene transcription (Li and Chiang, 2005). However, in vivo administration of the PXR ligand rifampicin did not significantly reduce CYP7A1 expression or bile acid synthesis in humans (Lutjohann et al., 2004; Marschall et al., 2005) questioning the physiologic significance of PXR-mediated repression.

\section{Bile acid transport}

Both CAR and PXR not only coordinate detoxification enzymes but also regulate transport of products of phases I and II detoxification. CAR and PXR share the same response element in rat Mrp2 promoter together with FXR (Kast et al., 2002), and ligands for these receptors induce MRP2/Mrp2 expression (Courtois et al., 1999; 2002; Cherrington et al., 2002; Kast et al., 2002; Guo et al., 2003; Marschall et al., 2005; Teng and Piquette-Miller, 2005; Wagner et al., 2005). Both NRs also positively regulate basolateral MRP3/Mrp3 expression while only CAR but not PXR ligands induce MRP4/Mrp4 (Cherrington et al., 2002; Guo et al., 2003; Teng et al., 2003; Assem et al., 2004; Zhang et al., 2004a; Maher et al., 2005; Wagner et al., 2005). Taken together, both PXR and CAR play a central role in regulating the elimination of phases I and II detoxification products from hepatocytes.
Increased bile acid toxicity in PXR and CAR knockout models The importance of both PXR and CAR in the defence against cholestasis is underlined by multiple studies. Mice lacking PXR develop increased liver injury after LCA feeding due to absent Cyp3a11 induction (Staudinger et al., 2001b; Xie et al., 2001). In contrast, a recent paper reported reduced liver injury in mice lacking PXR fed CA (Teng and Piquette-Miller, 2007). The authors attributed these controversial results to higher basal expression levels of Cyp3a11, Ost $\alpha /$ Ost $\beta$, Mrp2 and Mrp3 in PXR knockout animals. These data are also in line with increased bilirubin clearance due to increased expression of bilirubin-detoxifying enzymes and transporters in PXR knockout mice (Saini et al., 2005). The increased expression of CAR target genes in these studies may be explained by de-repression of the constitutive activity of CAR in the absence PXR (Saini et al., 2005). CAR knockout and CAR/PXR double knockout animals showed similar sensitivity to bilirubin challenge as wild-type mice (Saini et al., 2005). In addition, the combined loss of PXR and CAR results in increased sensitivity to LCA-induced liver injury when compared with loss of PXR or CAR alone (Uppal et al., 2005). Similar findings were observed in FXR/PXR double knockout mice displaying more severe toxicity in response to $\mathrm{CA}$ feeding than mice lacking FXR or PXR alone (Guo et al., 2003). These data indicate, that PXR, CAR but also FXR protect against hepatic bile acid-induced toxicity in a complementary manner regulating redundant but distinct defence pathways.

\section{PXR and fibrosis}

In addition to FXR, PXR also seems to play a role in modulating liver fibrosis. The PXR ligand PCN inhibited HSC transdifferentiation to a pro-fibrogenic phenotype in a noncholestatic model of liver fibrosis in rats (Marek et al., 2005). In addition, rifampicin inhibited the expression of various fibrosis- and proliferation-related genes in human HSCs and reduced HSC proliferation and transdifferentiation in a PXRdependent manner (Haughton et al., 2006). One explanation of PXR's inhibitory effects on liver fibrosis could be PXRdependent inhibition of NF- $\mathrm{KB}$ leading to reduced inflammation (Axon et al., 2008). However, the exact molecular mechanisms remain to be determined. Whether these findings also can be extended to therapy of fibrosis and cirrhosis caused by long-lasting cholestasis is currently unknown.

\section{Therapeutic targeting of PXR and CAR}

Because of their central role in bile acid detoxification and transport, PXR and CAR represent attractive targets for drug therapy of cholestasis (Table 1). Ligands for both receptors have already been used to treat cholestasis even long before their mode of action has been explored. Rifampicin is a ligand for PXR and is effectively used to treat pruritus of cholestasis but also ameliorates elevated liver function tests (Bachs et al., 1989; Cancado et al., 1998; Yerushalmi et al., 1999). The CAR agonist phenobarbital not only improves pruritus but also reduces serum bile acid concentrations in cholestasis (Stiehl et al., 1972; Bloomer and Boyer, 1975; Bachs et al., 1989). However, both drugs can cause significant side effects ranging 
from fatigue and somnolence (phenobarbital) to hepatoxicity and liver failure (rifampicin) (Bachs et al., 1992; Prince et al., 2002). NR ligands have also been used in traditional Chinese medicine for centuries. For example, Yin Zhin Huang and a number of other herbal decoctions containing Yin Chin have been used in Asia to prevent and treat neonatal jaundice. Yin Chin has been identified as a CAR ligand and accelerates bilirubin clearance in vivo (Huang et al., 2004). The underlying molecular mechanisms of the beneficial effects of these PXR and CAR ligands have been elucidated in various animal models over the last years. In a rodent model, activation of PXR counteracted LCA-induced liver toxicity by induction of Cyp3a11, Sult2a1 and 3'-phosphoadenosine 5'phosphosulfate synthase 2 (PAPSS2), an enzyme that generates the sulphate donor for the sulphation reaction (Staudinger et al., 2001b; Xie et al., 2001; Saini et al., 2004). PXR activation also induced bilirubin detoxification and clearance via induction of its glucuronidation and export (Kast et al., 2002; Chen et al., 2003a; Ellis et al., 2006). Administration of PXR ligands reduced liver injury, bilirubin and bile acid levels in CA-fed mice via induction of Cyp3a11 and Mrp3 (Teng and Piquette-Miller, 2007). In obstructive cholestasis in mice, administration of PXR and CAR ligands reduced serum parameters of cholestasis (i.e. bilirubin and serum bile acid levels) by induction of phases I and II detoxification and transport systems (Wagner et al., 2005). However, increased transaminases in these animals indicate potential hepatotoxic side effects of the used substances at least under conditions when bile flow is completely blocked (Wagner et al., 2005). Stimulation of PXR and CAR may be therapeutically superior to activation of FXR in obstructive cholestasis because this does not increase bile flow. However, these substances should be used with care because of potential hepatotoxicty when biliary elimination is hampered and the risk of promoting hepatic cancerogenesis via continuous stimulation of CAR (Yamamoto et al., 2004; Huang et al., 2005). Novel compounds targeting PXR and CAR with fewer side effects are needed for the treatment of cholestasis. Whether herbals from traditional Chinese medicine in analogy to Yin Chin may contribute to the armentarium of CAR and PXR agonists needs further exploration.

\section{VDR (NR1I1)}

The VDR is a member of the superfamily of steroid hormone receptors and regulates calcium homeostasis, cell proliferation and differentiation, and exerts immunomodulatory as well as antimicrobial functions (Campbell and Adorini, 2006). VDR binds to and mediates the calcemic effects of calcitriol (1 $\alpha, 25$-dihydroxyvitamin D3) after forming an heterodimer with RXR. $1 \alpha, 25$-dihydroxyvitamin D3 negatively regulates its own synthesis by repressing the 25-hydroxyvitamin $\mathrm{D}_{3}$ 1 $\alpha$-hydroxylase (CYP27B1) (Turunen et al., 2007).

VDR has been demonstrated to be an intestinal receptor for LCA (Makishima et al., 2002). Activation of VDR by vitamin D or LCA in vitro induces expression of CYP3A4, which can detoxify LCA via phase I hydroxylation (Makishima et al., 2002). Expression of VDR however is high in intestine but low in liver (McCarthy et al., 2005), where it is restricted to
Kupffer cells, endothelial cells, biliary epithelial cells and HSCs (Gascon-Barre et al., 2003). Despite low hepatic VDR expression, LCA, vitamin D and a synthetic VDR ligand were able to stimulate Cyp3a11 expression in mouse liver (Makishima et al., 2002). These effects were also present in mice lacking PXR indicating a VDR-mediated stimulation of Cyp3a11. SULT2A1/Sult2a1 is another target for VDR (Echchgadda et al., 2004). Vitamin D stimulates SULT2A1/Sult2a1 expression in HepG2 cells in vitro as well as in vivo in mice (Chatterjee et al., 2005), indicating that even low VDR expression in hepatocytes may be sufficient to up-regulate Sult2a1. Mrp3 also harbours a VDR response element in its promoter region and is transactivated upon calcitriol and LCA treatment (McCarthy et al., 2005). However, Mrp3 induction was only present in colon but not in liver (McCarthy et al., 2005). The ileal bile acid uptake system apical sodium-dependent bile acid transporter (ASBT) is another target of VDR, and calcitriol increases $A S B T$ mRNA and promoter activity (Chen et al., 2006). Moreover, VDR seems to play an indirect role in bile acid homeostasis because VDR negatively interacts with FXR and calcitriol inhibits FXR transactivation in vitro (Honjo et al., 2006).

Thus VDR is an important regulator of bile acid transport and metabolism in the intestine due to its high expression in enterocytes but also plays an important role in hepatic phases I and II detoxification reactions (Fig. 3, Table 1). The use of vitamin D or synthetic VDR agonist represents an attractive therapeutic option to treat cholestatic liver diseases and should be investigated in future studies. However, the rather complex role of VDR in regulation of bile acid uptake in intestine and regulation of bile acid metabolism in liver as well as its negative effects on FXR makes the outcome of such studies rather unpredictable.

\section{Peroxisome proliferator-activated receptors (PPARs)}

PPARs are ligand-activated NRs that heterodimerize with RXR and bind to DR-1 response elements upon activation (Willson et al., 2000; Brown and Plutzky, 2007). PPAR $\alpha, \beta, \gamma$ are dietary lipid sensors, which control lipid homeostasis and cellular differentiation from adipocytes. As such, almost all occurring natural fatty acids and eicosanoids are natural ligands for PPARs. PPAR $\alpha$ (NR1C1) is highly expressed in heart, liver, kidney and brown fat, tissues with a high rate of $\beta$-oxidation of fatty acids, while PPAR $\gamma$ (NR1C3) is mainly expressed in white adipose tissue (Brown and Plutzky, 2007). PPARs regulate the expression of various genes crucial for lipid, glucose, bile acid and drug metabolism (Kota et al., 2005; Nakata et al., 2006).

\section{PPAR $\alpha$ (NR1C1)}

PPAR $\alpha$ is involved in the regulation of bile acid metabolism indicated by the presence of PPAR response elements in the SULT2A1 and UGT2B4 gene promoters. These genes are activated by lipid-lowering fibrates, which are PPAR $\alpha$ activators (Willson et al., 2000; Barbier et al., 2003a; Fang et al., 2005). 
In addition, there is crosstalk between the PPAR $\alpha$ and FXR transcriptional pathways because PPAR $\alpha$ is an FXR target gene harbouring an FXR response element in its gene promoter (Pineda et al., 2003). For example, UGT2B4 expression can be directly induced via activation of PPAR $\alpha$ and indirectly via FXR-dependent induction of PPAR $\alpha$, which then activates UGT2B4 transcription. Treatment of human hepatocytes with fibrates as classic PPAR $\alpha$ ligands induced expression and activity of UGT1A3, which is responsible for the glucuronidation of CDCA (Trottier et al., 2006). PPAR $\alpha$ also negatively affects bile acid synthesis by repressing CYP7A1 by reducing HNF4 $\alpha$ binding to the DR-1 response element in the CYP7A1 promoter (Marrapodi and Chiang, 2000; Patel et al., 2000; Post et al., 2001; Rudling et al., 2002; Roglans et al., 2004).

PPAR $\alpha$ is not only involved in regulation of bile acid synthesis and detoxification but also modulates biliary phospholipid secretion. Phospholipids protect the bile duct epithelium from detergent bile acids by formation of mixed micelles. Fibrates and other PPAR $\alpha$ activators directly induce expression of Mdr2 in the canalicular membrane thereby inducing biliary phospholipid output (Chianale et al., 1996; Miranda et al., 1997; Kok et al., 2003; Shoda et al., 2004). PPAR $\alpha$ induces ASBT/Asbt expression in liver (cholangiocytes) and intestine (Jung et al., 2002) resulting in increased bile acid absorption from the intestine and bile ducts. Reabsorption of bile acids from obstructed bile ducts might minimize cholangiocyte damage.

The effects of PPAR $\alpha$ on biliary phospholipid secretion, bile acid metabolism and synthesis make stimulation of PPAR $\alpha$ an interesting therapeutic approach in the treatment of cholestasis (Table 1). Especially increased phospholipid secretion into bile may reduce the aggressiveness of bile thus protecting cholangiocytes. Fenofibrate administration to bile duct-ligated rats moderately reduced serum markers of cholestasis and histological parameters liver injury. However, these effects were only moderate (Cindoruk et al., 2007). Clinical trials by using fibrates showed beneficial effects on biochemical parameters and in part also on histological findings in patients with PBC (Kurihara et al., 2000; Nakai et al., 2000; Ohmoto et al., 2001; Kurihara et al., 2002; Yano et al., 2002; Kanda et al., 2003). However, these studies were pilot studies including only a small number of patients and where not randomized controlled trials. Inhibitors of 3-hydroxy-3-methylglutarylcoenzyme A reductase ('statins') are PPAR $\alpha$ activators and stimulate phospholipid secretion by induction of Mdr2 (Carrella et al., 1999; Hooiveld et al., 1999; Landrier et al., 2004) Statins have also been tested in the treatment of PBC. While initial mostly anecdotal reports suggested improvement of cholestasis under statin treatment (Kurihara et al., 1993; Kamisako and Adachi, 1995; Ritzel et al., 2002), a recent dose finding study was unable to demonstrate improvement of cholestasis in PBC patients with an incomplete prior response to UDCA (Stojakovic et al., 2007). Whether long-term application of PPAR $\alpha$ ligands improves cholestasis and disease outcome in a larger cohort of patients remains to be demonstrated. Currently, a phase II study is under way investigating the effects of fenofibrate in PBC patients with incomplete response to UDCA (Table 2). However, results of this study will not be available before 2010 .

\section{PPAR $\gamma($ NR1C3)}

PPAR $\gamma$ is therapeutically targeted by thiazolidinediones (glitazones) and is a key regulator of adipogenesis and insulin sensitivity. The transcriptional coactivator PGC- $1 \alpha$ orchestrates PPAR $\gamma$ effects thus playing a critical role in the regulation of mitochondrial functional capacity and cellular energy metabolism. Of note, PGC- $1 \alpha$ also targets many other NRs including PPAR $\alpha$, PPAR $\beta$, thyroid hormone receptor, retinoid receptors, GR, oestrogen receptor, FXR, PXR, HNF4 $\alpha$, liver X receptor (LXR) and the oestrogen-related receptors (Finck and Kelly, 2006). While PPAR $\gamma$ induces expression of the cholesterol transporters ABCA1 and ABCG1 and ABCG2 (a protective pump against toxic agents) (Takeda et al., 2000; Szatmari et al., 2006), a direct role for PPAR $\gamma$ in the regulation of bile acid homeostasis has not yet been reported. A PPAR $\gamma / \mathrm{RXR} \alpha$ heterodimer has been shown to bind to a PPAR response element in the SHP promoter and rosiglitazone increased SHP expression in primary rat hepatocytes (Kim et al., 2007a). Whether PPAR $\gamma$ ligands affect bile acid homeostasis via this pathway in vivo remains to be determined. However, PPAR $\gamma$ agonists might be of use in inflammatory cholestasis. Pretreatment of lipopolysaccharide (LPS)-injected mice with rosiglitazone attenuated repression of Ntcp, Bsep and Cyp3a11 without affecting cytokine levels (Ghose et al., 2007). These anti-cholestatic effects were attributed to prevention of the nuclear export of RXR $\alpha$ caused by LPS (Ghose et al., 2004; Ghose et al., 2007). In addition, PPAR $\gamma$ represses transcriptional activation of inflammatory response genes in mouse macrophages by a complex mechanism involving SUMOylation of the PPAR $\gamma$ ligand-binding domain. This prevents recruitment of the ubiquitination/19S proteosome machinery that normally mediates the signal-dependent removal of corepressor complexes required for gene activation. As a result, NCoR complexes are not cleared from the promoter and proinflammatory target genes are maintained in a repressed state (Pascual et al., 2005). Moreover, PPAR $\gamma$ agonists inhibit HSC activation and counteract liver fibrosis in models of cholestasis (Dubuquoy et al., 2002; Galli et al., 2002; Fiorucci et al., 2005b). The crosstalk between FXR and PPAR $\gamma$ is described above.

Safety issues are an important concern when using glitazones. Troglitazone was the first glitazone on the market but was withdrawn later because of hepatotoxic side effects (Lee, 2003). Second generation glitazones like rosiglitazone and pioglitazone are rarely associated with liver injury; however, the manufacturers do not recommend the use of these substances in patients with liver disease. These drugs show beneficial effects in non-alcoholic fatty liver disease and do not seem to lead to liver injury in patients with fatty liver and increased baseline liver function tests (Belfort et al., 2006; Caldwell et al., 2006). However, the use of these drugs in cholestasis could have hepatotoxic side effects. Glitazones have been demonstrated to inhibit $\mathrm{Na}^{+}$- and ATP-dependent bile acid transport in a dose dependent manner (Funk et al., 2001; Snow and Moseley, 2007). This was evident for rosiglitazone, ciglitazone and troglitazone indicating a class effect (Snow and Moseley, 2007). Beneficial effects of troglitazone observed in a rat model of obstructive cholestasis on cholangiocellular proliferation and fibrosis have not yet been extended to other models (Marra et al., 2005). Taken together, 
glitazones should be tested with great care in patients with cholestasis.

\section{$\operatorname{LXR} \alpha(\mathrm{NR} 1 \mathrm{H} 3)$ and LXR $\beta(\mathrm{NR} 1 \mathrm{H} 2)$}

The LXR subfamily consists of $\operatorname{LXR} \alpha$ and $\operatorname{LXR} \beta$. LXR $\alpha$ is mainly expressed in liver, adipose tissue, intestine, kidney and macrophages whereas LXR $\beta$ is ubiquitously expressed (Lu et al., 2001). LXR $\alpha$ and LXR $\beta$ are activated by naturally occurring oxysterols, certain unsaturated fatty acids and $6 \alpha$-hydroxylated bile acids (Song et al., 2000; Lu et al., 2001; Ou et al., 2001). Both LXRs heterodimerize with RXR and preferentially bind to DR-4 DNA response elements.

LXR $\alpha$ acts as a cholesterol sensor and regulates cholesterol and lipid homeostasis. In cholesterol-enriched diet-fed rodents, the expression of Cyp7a1 is induced via $\operatorname{LXR} \alpha$, which is activated by oxysterol metabolites of cholesterol (Janowski et al., 1996; Lehmann et al., 1997). In contrast to rodent Cyp7a1, human CYP7A1 is repressed upon activation of LXR $\alpha$ (Chiang et al., 2001; Goodwin et al., 2003), which was attributed to induction of LXR $\alpha$-activated SHP (Goodwin et al., 2003). LXR $\alpha$ also regulates various genes involved in lipid metabolism including ABCA1, ABCG1, ABCG4, ABCG5, and ABCG8, apolipoprotein E, cholesterol ester transport protein, lipoprotein lipase, fatty acid synthase, and the sterol-regulatory element-binding protein 1 (SREBP-1), a key transcription factor for regulation of hepatic lipogenesis (Tall et al., 2000; Edwards et al., 2002; Laffitte and Tontonoz, 2002; Repa et al., 2002). In addition, $\mathrm{LXR} \alpha$ modulates immune and inflammatory responses in macrophages (Zelcer and Tontonoz, 2006). LXR activation inhibits LPS-mediated induction of various proinflammatory cytokines (Joseph et al., 2003). This mechanism has been linked to SUMOylation-dependent pathways. Liganddependent conjugation of SUMO2/3 to LXR prevents the signal-dependent removal of the corepressor NCoR from proinflammatory genes leading to transrepression of inflammation (Ghisletti et al., 2007).

A role for $\mathrm{LXR} \alpha$ in reducing cholestatic liver injury has recently been demonstrated. In this study, LXR $\alpha$-transgenic mice and mice treated with a synthetic LXR $\alpha$ agonist were resistant to liver damage induced by LCA feeding and bile duct ligation (Uppal et al., 2007). Moreover, LXR knockout animals displayed severe liver injury after bile duct ligation. The beneficial effects of $\mathrm{LXR} \alpha$ stimulation were attributed to increased expression of sulfotransferase Sult2a9 and Mrp4 leading to increased urinary bile acid elimination (Uppal et al., 2007). Interestingly, the findings regarding protection by Sult2a9 induction via LXR were restricted to female mice, and the protective effects of LXR were absent in male mice exposed to cholestatic injury. The underlying mechanism still remains unresolved but may be linked to sex hormonedependent regulation of detoxifying enzymes (Uppal et al., 2007). In addition, the bile acid-glucuronidating enzyme UGT1A3 has also been identified as a LXR $\alpha$ target with a LXR response element in its gene promoter (Verreault et al., 2006). Thus, $\mathrm{LXR} \alpha$ is not only an attractive target for intervention in metabolic disorders but also for the treatment of cholestasis.

\section{GR (NR3C1)}

The GR is ubiquitously expressed in the body and regulates numerous functions including repression of transcriptional responses to inflammatory signals. The natural ligands for GR are glucocorticoids but also UDCA was reported to activate GR (Tanaka and Makino, 1992; Miura et al., 2001). GR transactivates human NTCP (Eloranta et al., 2006) and ASBT (Jung et al., 2004a). GR also appears to modulate anion exchanger AE2 expression (Alvaro et al., 2002; Arenas et al., 2008). Interestingly, the combination of UDCA and the GR ligand dexamethasone but not UDCA or dexamethasone alone increased AE2 expression and function via interaction of HNF1 and GR on the AE2 alternate promoter (Arenas et al., 2008). These findings might explain the beneficial effects of the combination of glucocorticoids and UDCA in patients with PBC, because AE2 expression is reduced in PBC (Prieto et al., 1993). A role for glucocorticoids has been suggested for the regulation of Bsep in rat hepatocytes in vitro (Warskulat et al., 1999) but this has been questioned by other studies (Gerloff et al., 2002; Cheng et al., 2007). A GR response element has so far not been identified in the Bsep promoter. Rodent Mrp2 is stimulated by dexamethasone (Courtois et al., 1999; Kubitz et al., 1999; Turncliff et al., 2004), while human MRP2 is unaffected after dexamethasone treatment (Pulaski et al., 2005; Nishimura et al., 2006). One has to be aware that effects of glucocorticoids may not only be direct effects of GR on target genes but may also be modulated indirectly by other NRs. As such, CAR has been identified as a primary GR response gene with a glucocorticoid responsive element in its promoter region. In addition, glucocorticoids increase the levels of PXR and RXR $\alpha$ mRNA and protein (Pascussi et al., 2000; 2003). In addition to its transcriptional induction, dexamethasone also increases translocation of CAR protein into the nucleus (Pascussi et al., 2000). Taken together, GR modulates and potentiates action of PXR and CAR target genes, but also directly regulates expression of various genes involved in bile acid transport and detoxification.

Glucocorticoids have been used in the treatment of various cholestatic disorders. Beneficial effects of glucocorticoids (i.e. prednisone, budesonide) on serum parameters of cholestasis and liver histology have been noted especially when added to the standard treatment with UDCA (Mitchison et al., 1992; Leuschner et al., 1996; 1999; Rautiainen et al., 2005). Whether these effects are only the consequence of the antiinflammatory properties or whether they can in part be attributed to modulation of bile acid transport and metabolism remains elusive.

\section{LRH-1 (NR5A1)}

LRH-1 is expressed in tissues derived from endoderm, including intestine, liver and exocrine pancreas, as well as in the ovary. In these tissues, LRH-1 plays a predominant role in development, reverse cholesterol transport, steroidogenesis and bile acid homeostasis (Fayard et al., 2004). For a long time, LRH-1 was considered to be an orphan NR, but recently, phospholipids were shown to bind human LRH-1 (Krylova et al., 2005; Ortlund et al., 2005; Wang et al., 2005). 
LRH-1-binding sites have been identified in the promoters of CYP7A1 and CYP8B1 (Nitta et al., 1999; Castillo-Olivares and Gil, 2000). LRH-1 has also been implicated in repression of these enzymes via a FXR/SHP-dependent mechanisms (Goodwin et al., 2000; Lu et al., 2000). However, this was questioned by a recent study demonstrating preserved FXRmediated repression of Cyp7a1 and Cyp8b1 in liver-specific LRH-1 knockout mice (Lee et al., 2008). The repressive effects of FXR on Cyp7a1 in this study were attributed to SHP-mediated repression of $\mathrm{HNF} 4 \alpha$, which also binds to the same response element in the Cyp7a1 promoter (Lee et al., 2000; De Fabiani et al., 2001). While basal expression of Cyp7a1 was unaffected in LRH-1 deficient mice, Cyp8b1 expression was markedly reduced (Mataki et al., 2007; Lee et al., 2008). Bile acid pool composition in these animals changed drastically towards a more hydrophilic pool with low levels of CA but higher levels of muricholic acid and UDCA, while levels of CDCA and DCA acid remained unchanged (Mataki et al., 2007). Loss of LRH-1 had also dramatic effects on expression of hepatobiliary transport systems and NRs. Expression of Ntcp, Bsep, Mrp3, Mrp2, Mdr2, FXR and SHP was markedly reduced in these animals (Mataki et al., 2007; Lee et al., 2008). Some of these findings can be attributed to direct LRH-1-mediated target gene activation as described for MRP3/Mrp3 (Inokuchi et al., 2001; Bohan et al., 2003), Bsep (Song et al., 2008), Asbt (Chen et al., 2003b), Ost $\alpha /$ Ost $\beta$ (Frankenberg et al., 2006), FXR and SHP (Oiwa et al., 2007). Decreased expression of FXR may also contribute to low expression of its target genes (i.e. Bsep, Mdr2, Mrp2 and SHP) (Goodwin et al., 2000; Lu et al., 2000; Ananthanarayanan et al., 2001; Gerloff et al., 2002; Plass et al., 2002; Moschetta et al., 2004). Two recent studies in LRH-1-deficient mice indicate a central role for this receptor in the regulation of bile acid homeostasis (Mataki et al., 2007; Lee et al., 2008). Whether LRH-1 knockout mice are more susceptible (due to reduced transporter expression) or on the contrary even protected from cholestatic injury (due to a more hydrophilic bile acid pool) remains to be investigated. Therapeutic targeting of LRH-1 has not been tested so far but would be expected to lead to deregulation of a large number of genes involved in bile acid metabolism, and the subsequent effects are hardly predictable.

\section{$\mathrm{HNF} 4 \alpha(N R 2 A 1)$}

HNF $4 \alpha$ is a highly conserved member of the NR superfamily and is expressed at highest levels in liver, intestine, kidney and pancreas (Miquerol et al., 1994; Sladek, 1994). HNF4 $\alpha$ has an essential role in development, oncogenesis and maintenance of organ function (Odom et al., 2004). HNF $4 \alpha$ functions as a homodimer and can activate gene transcription in the absence of exogenous ligands (Sladek et al., 1990; Ladias et al., 1992). Fatty acids may be ligands for HNF4 $\alpha$ (Dhe-Paganon et al., 2002; Wisely et al., 2002), and fatty acylcoenzyme A (CoA) thioesters may modulate HNF4 $\alpha$-binding activity (Hertz et al., 1998), suggesting an important role in the control of metabolic status. Furthermore, mutations in the HNF $4 \alpha$ gene cause maturity onset diabetes of the young (MODY1), a rare form of non-insulin-dependent diabetes mellitus inherited in an autosomal dominant pattern and characterized by defective secretion of insulin (Yamagata et al., 1996; Dhe-Paganon et al., 2002; Wisely et al., 2002). A number of CYP genes including CYP3A4/Cyp3 harbour putative $H N F 4 \alpha$-binding sites in their promoter and enhancer sequences and $\mathrm{HNF} 4 \alpha$ positively regulates their gene expression (Huss and Kasper, 1998; Ogino et al., 1999; Tirona et al., 2003; Matsumura et al., 2004). Furthermore, HNF $4 \alpha$ regulates the basal and CAR-/PXR-induced expression of human SULT2A1 (Echchgadda et al., 2007). HNF4 $\alpha$ is also an important regulator of bile acid synthesis. CYP7A1, CYP27A1 and CYP8B1 harbour HNF4 $\alpha$-binding sites in their gene promoters (Zhang and Chiang, 2001; Yang et al., 2002; Chen and Chiang, 2003). HNF $4 \alpha$ may be the key target of FXR-activated SHP leading to suppression of Cyp7a1 and Cyp8b1 expression (Mataki et al., 2007; Lee et al., 2008).

In addition to direct target gene regulation, $\mathrm{HNF} 4 \alpha$ may also indirectly act via activation of other NRs. An HNF $4 \alpha$-binding site was characterized in the $P X R$ promoter thereby regulating responses to xenobiotics through activation of the $P X R$ gene during fetal liver development (Li et al., 2000; Kamiya et al., 2003). The human CAR promoter is regulated by HNF4 $\alpha$ (Ding et al., 2006), and expression of CAR is reduced in mice lacking HNF $4 \alpha$ (Tirona et al., 2003). Moreover, FXR and PPAR $\alpha$ gene transcription is activated by HNF4 $\alpha$ (Lu et al., 2000; Pineda Torra et al., 2002; Zhang et al., 2004b). HNF4 $\alpha$ is also a critical regulator of the liver-enriched transcription factor HNF1 $\alpha$ (Tian and Schibler, 1991; Miura and Tanaka, 1993; Wang et al., 2001; Jung and Kullak-Ublick, 2003), which itself plays a key role in the regulation of bile acid transport and metabolism (Shih et al., 2001; Arrese and Karpen, 2002).

Taken together, these data indicate that HNF $4 \alpha$ is a major regulator of genes involved in the control of bile acid homeostasis. HNF $4 \alpha$ controls target genes either directly or indirectly via interactions with other NRs and transcription factors. Targeting HNF $4 \alpha$ in cholestasis has not yet been tested, but many side effects are to be expected due to its central role in regulation of organ development function and the metabolism.

\section{Conclusions and outlook}

NRs are critically involved in regulation of bile formation and bile acid homeostasis under physiological and pathological conditions. Various compounds accumulate as a result of bile secretory failure in cholestasis and induce a complex machinery of defence pathways involving bile acid detoxification, synthesis and transport via activation of NRs. However, these intrinsic adaptive mechanisms do not suffice to overcome cholestatic liver injury damage. Therefore, additional stimulation of these defence pathways represents an attractive target of drug therapy (Fig. 3). Some NR activators (e.g. phenobarbital, rifampicin) are already successfully used in the treatment of cholestasis on an empiric basis and have been introduced as therapeutics long before their mode of action was identified. However, these drugs are sometimes associated with substantial side effects including severe liver injury. In addition, NR ligands stimulating bile flow may cause hepatotoxicity when bile duct obstruction or substantial bile duct loss is present. The increasing knowledge on the pathomechanisms of cholestasis and the action of NRs in health and 
disease made the use NR ligands possible while keeping their potential side effects minimal. Clinical trials have already investigated or currently investigate the effects of various NR ligands (e.g. FXR, PPAR $\alpha$ and GR ligands) in human cholestatic disorders. Some clinical results have been disappointing and have not fulfilled the expectations that were raised based on animal experimental findings. However, initiation of such studies would not haven been possible without the increasing knowledge on NR function in cholestasis derived from in vitro experiments, animal models of cholestasis as well as from human liver disease. Further basic research in the field will probably identify other, more potent substances with a lower rate of side effects, which hopefully can be applied to human cholestatic diseases.

\section{Acknowledgements}

This work was supported by Grants No. P18613-BO5 and P19118-B05 from the Austrian Science Foundation and by a GEN-AU grant from the Austrian Ministry for Science (to M.T).

\section{Conflicts of interest}

None.

\section{References}

Alme B, Sjovall J (1980). Analysis of bile acid glucuronides in urine. Identification of 3 alpha, 6 alpha, 12 alpha-trihydroxy-5 betacholanoic acid. J Steroid Biochem 13 (8): 907-916.

Alme B, Bremmelgaard A, Sjovall J, Thomassen P (1977). Analysis of metabolic profiles of bile acids in urine using a lipophilic anion exchanger and computerized gas-liquid chromatorgaphy-mass spectrometry. J Lipid Res 18 (3): 339-362.

Alvaro D, Gigliozzi A, Marucci L, Alpini G, Barbaro B, Monterubbianesi R et al. (2002). Corticosteroids modulate the secretory processes of the rat intrahepatic biliary epithelium. Gastroenterology 122 (4): 1058-1069.

Ananthanarayanan M, Balasubramanian N, Makishima M, Mangelsdorf DJ, Suchy FJ (2001). Human bile salt export pump promoter is transactivated by the farnesoid X receptor/bile acid receptor. J Biol Chem 276 (31): 28857-28865.

Araya Z, Wikvall K (1999). 6alpha-hydroxylation of taurochenodeoxycholic acid and lithocholic acid by CYP3A4 in human liver microsomes. Biochim Biophys Acta 1438 (1): 47-54.

Arenas F, Hervias I, Uriz M, Joplin R, Prieto J, Medina JF (2008). Combination of ursodeoxycholic acid and glucocorticoids upregulates the AE2 alternate promoter in human liver cells. J Clin Invest 118 (2): 695-709.

Arrese M, Karpen SJ (2002). HNF-1 alpha: have bile acid transport genes found their 'master'? J Hepatol 36 (1): 142-145.

Assem M, Schuetz EG, Leggas M, Sun D, Yasuda K, Reid G et al. (2004). Interactions between hepatic Mrp4 and Sult2a as revealed by the constitutive androstane receptor and Mrp4 knockout mice. J Biol Chem 279 (21): 22250-22257.

Axon A, Cowie DE, Mann DA, Wright MC (2008). A mechanism for the anti-fibrogenic effects of the pregnane $\mathrm{X}$ receptor (PXR) in the liver: Inhibition of NF-kappaB? Toxicology 246 (1): 40-44.

Bachs L, Pares A, Elena M, Piera C, Rodes J (1989). Comparison of rifampicin with phenobarbitone for treatment of pruritus in biliary cirrhosis. Lancet 1 (8638): 574-576.
Bachs L, Pares A, Elena M, Piera C, Rodes J (1992). Effects of long-term rifampicin administration in primary biliary cirrhosis. Gastroenterology 102 (6): 2077-2080.

Barbier O, Duran-Sandoval D, Pineda-Torra I, Kosykh V, Fruchart JC, Staels B (2003a). Peroxisome proliferator-activated receptor alpha induces hepatic expression of the human bile acid glucuronidating UDP-glucuronosyltransferase 2B4 enzyme. J Biol Chem 278 (35): 32852-32860.

Barbier O, Torra IP, Sirvent A, Claudel T, Blanquart C, Duran-Sandoval $\mathrm{D}$ et al. (2003b). FXR induces the UGT2B4 enzyme in hepatocytes: a potential mechanism of negative feedback control of FXR activity. Gastroenterology 124 (7): 1926-1940.

Belfort R, Harrison SA, Brown K, Darland C, Finch J, Hardies J et al. (2006). A placebo-controlled trial of pioglitazone in subjects with nonalcoholic steatohepatitis. N Engl J Med 355 (22): 2297-2307.

Berge Henegouwen GP, Brandt KH, Eyssen H, Parmentier G (1976). Sulphated and unsulphated bile acids in serum, bile, and urine of patients with cholestasis. Gut 17 (11): 861-869.

Bertilsson G, Heidrich J, Svensson K, Asman M, Jendeberg L, SydowBackman M et al. (1998). Identification of a human nuclear receptor defines a new signaling pathway for CYP3A induction. Proc Natl Acad Sci USA 95 (21): 12208-12213.

Bloomer JR, Boyer JL (1975). Phenobarbital effects in cholestatic liver diseases. Ann Intern Med 82 (3): 310-317.

Bodin K, Lindbom U, Diczfalusy U (2005). Novel pathways of bile acid metabolism involving CYP3A4. Biochim Biophys Acta 1687 (1-3): 84-93.

Bohan A, Chen WS, Denson LA, Held MA, Boyer JL (2003). Tumor necrosis factor alpha-dependent up-regulation of Lrh-1 and Mrp3(Abcc3) reduces liver injury in obstructive cholestasis. $J$ Biol Chem 278 (38): 36688-36698.

Bremmelgaard A, Sjovall J (1979). Bile acid profiles in urine of patients with liver diseases. Eur J Clin Invest 9 (5): 341-348.

Bremmelgaard A, Sjovall J (1980). Hydroxylation of cholic, chenodeoxycholic, and deoxycholic acids in patients with intrahepatic cholestasis. J Lipid Res 21 (8): 1072-1081.

Brown JD, Plutzky J (2007). Peroxisome proliferator-activated receptors as transcriptional nodal points and therapeutic targets. Circulation 115 (4): 518-533.

Caldwell SH, Argo CK, Al-Osaimi AM (2006). Therapy of NAFLD: insulin sensitizing agents. J Clin Gastroenterol 40 (3 Suppl. 1): S61S66.

Campbell MJ, Adorini L (2006). The vitamin D receptor as a therapeutic target. Expert Opin Ther Targets 10 (5): 735-748.

Cancado EL, Leitao RM, Carrilho FJ, Laudanna AA (1998). Unexpected clinical remission of cholestasis after rifampicin therapy in patients with normal or slightly increased levels of gamma-glutamyl transpeptidase. Am J Gastroenterol 93 (9): 1510-1517.

Carrella M, Feldman D, Cogoi S, Csillaghy A, Weinhold PA (1999). Enhancement of mdr2 gene transcription mediates the biliary transfer of phosphatidylcholine supplied by an increased biosynthesis in the pravastatin-treated rat. Hepatology 29 (6): 1825-1832.

Castillo-Olivares A, Gil G (2000). Alpha 1-fetoprotein transcription factor is required for the expression of sterol 12alpha-hydroxylase, the specific enzyme for cholic acid synthesis. Potential role in the bile acid-mediated regulation of gene transcription. J Biol Chem 275 (23): 17793-17799.

Chatterjee B, Echchgadda I, Song CS (2005). Vitamin D receptor regulation of the steroid/bile acid sulfotransferase SULT2A1. Methods Enzymol 400: 165-191.

Chawla A, Repa JJ, Evans RM, Mangelsdorf DJ (2001). Nuclear receptors and lipid physiology: opening the X-files. Science 294 (5548): 1866-1870.

Chen C, Staudinger JL, Klaassen CD (2003a). Nuclear receptor, pregname $\mathrm{X}$ receptor, is required for induction of UDPglucuronosyltranferases in mouse liver by pregnenolone-16 alphacarbonitrile. Drug Metab Dispos 31 (7): 908-915. 
Chen F, Ma L, Dawson PA, Sinal CJ, Sehayek E, Gonzalez FJ et al. (2003b). Liver receptor homologue-1 mediates species- and cell line-specific bile acid-dependent negative feedback regulation of the apical sodium-dependent bile acid transporter. J Biol Chem 278 (22): 19909-19916

Chen F, Ananthanarayanan M, Emre S, Neimark E, Bull LN, Knisely AS et al. (2004). Progressive familial intrahepatic cholestasis, type 1, is associated with decreased farnesoid X receptor activity. Gastroenterology 126 (3): 756-764.

Chen W, Chiang JY (2003). Regulation of human sterol 27-hydroxylase gene (CYP27A1) by bile acids and hepatocyte nuclear factor 4alpha (HNF4alpha). Gene 313: 71-82.

Chen X, Chen F, Liu S, Glaeser H, Dawson PA, Hofmann AF et al. (2006). Transactivation of rat apical sodium-dependent bile acid transporter and increased bile acid transport by 1alpha,25dihydroxyvitamin D3 via the vitamin D receptor. Mol Pharmacol 69 (6): 1913-1923.

Cheng X, Buckley D, Klaassen CD (2007). Regulation of hepatic bile acid transporters Ntcp and Bsep expression. Biochem Pharmacol 74 (11): $1665-1676$.

Cherrington NJ, Hartley DP, Li N, Johnson DR, Klaassen CD (2002). Organ distribution of multidrug resistance proteins 1,2 , and 3 (Mrp1, 2, and 3) mRNA and hepatic induction of Mrp3 by constitutive androstane receptor activators in rats. J Pharmacol Exp Ther 300 (1): 97-104.

Chianale J, Vollrath V, Wielandt AM, Amigo L, Rigotti A, Nervi F et al. (1996). Fibrates induce mdr2 gene expression and biliary phospholipid secretion in the mouse. Biochem J 314 (Pt 3): 781-786.

Chiang JY (1998). Regulation of bile acid synthesis. Front Biosci 3: d176-d193.

Chiang JY (2004). Regulation of bile acid synthesis: pathways, nuclear receptors, and mechanisms. J Hepatol 40 (3): 539-551.

Chiang JY, Kimmel R, Weinberger C, Stroup D (2000). Farnesoid X receptor responds to bile acids and represses cholesterol 7alphahydroxylase gene (CYP7A1) transcription. J Biol Chem 275 (15): 10918-10924.

Chiang JY, Kimmel R, Stroup D (2001). Regulation of cholesterol 7alpha-hydroxylase gene (CYP7A1) transcription by the liver orphan receptor (LXRalpha). Gene 262 (1-2): 257-265.

Cindoruk M, Kerem M, Karakan T, Salman B, Akin O, Alper M et al. (2007). Peroxisome proliferators-activated alpha agonist treatment ameliorates hepatic damage in rats with obstructive jaundice: an experimental study. BMC Gastroenterol 7: 44.

Courtois A, Payen L, Guillouzo A, Fardel O (1999). Up-regulation of multidrug resistance-associated protein 2 (MRP2) expression in rat hepatocytes by dexamethasone. FEBS Lett 459 (3): 381-385.

Courtois A, Payen L, Le Ferrec E, Scheffer GL, Trinquart Y, Guillouzo A et al. (2002). Differential regulation of multidrug resistanceassociated protein 2 (MRP2) and cytochromes P450 2B1/2 and 3A1/2 in phenobarbital-treated hepatocytes. Biochem Pharmacol 63 (2): 333-341.

Cullen SN, Chapman RW (2006). The medical management of primary sclerosing cholangitis. Semin Liver Dis 26 (1): 52-61.

Dawson PA, Hubbert M, Haywood J, Craddock AL, Zerangue N, Christian WV et al. (2005). The heteromeric organic solute transporter alpha-beta, Ostalpha-Ostbeta, is an ileal basolateral bile acid transporter. J Biol Chem 280 (8): 6960-6968.

De Fabiani E, Mitro N, Anzulovich AC, Pinelli A, Galli G, Crestani M (2001). The negative effects of bile acids and tumor necrosis factoralpha on the transcription of cholesterol 7alpha-hydroxylase gene (CYP7A1) converge to hepatic nuclear factor-4: a novel mechanism of feedback regulation of bile acid synthesis mediated by nuclear receptors. J Biol Chem 276 (33): 30708-30716.

De Fabiani E, Mitro N, Gilardi F, Caruso D, Galli G, Crestani M (2003). Coordinated control of cholesterol catabolism to bile acids and of gluconeogenesis via a novel mechanism of transcription regulation linked to the fasted-to-fed cycle. J Biol Chem 278 (40): 39124-39132.
Denson LA, Sturm E, Echevarria W, Zimmerman TL, Makishima M, Mangelsdorf DJ et al. (2001). The orphan nuclear receptor, shp, mediates bile acid-induced inhibition of the rat bile acid transporter, ntcp. Gastroenterology 121 (1): 140-147.

Dhe-Paganon S, Duda K, Iwamoto M, Chi YI, Shoelson SE (2002). Crystal structure of the HNF4 alpha ligand binding domain in complex with endogenous fatty acid ligand. J Biol Chem 277 (41): 37973-37976.

Ding X, Lichti K, Kim I, Gonzalez FJ, Staudinger JL (2006). Regulation of constitutive androstane receptor and its target genes by fasting, cAMP, hepatocyte nuclear factor alpha, and the coactivator peroxisome proliferator-activated receptor gamma coactivator-1alpha. J Biol Chem 281 (36): 26540-26551.

Donner MG, Keppler D (2001). Up-regulation of basolateral multidrug resistance protein 3 (Mrp3) in cholestatic rat liver. Hepatology 34 (2): 351-359.

Dubuquoy L, Dharancy S, Nutten S, Pettersson S, Auwerx J, Desreumaux P (2002). Role of peroxisome proliferator-activated receptor gamma and retinoid $\mathrm{X}$ receptor heterodimer in hepatogastroenterological diseases. Lancet 360 (9343): 1410-1418.

Echchgadda I, Song CS, Roy AK, Chatterjee B (2004). Dehydroepiandrosterone sulfotransferase is a target for transcriptional induction by the vitamin D receptor. Mol Pharmacol 65 (3): 720-729.

Echchgadda I, Song CS, Oh T, Ahmed M, De La Cruz IJ, Chatterjee B (2007). The xenobiotic-sensing nuclear receptors pregnane $\mathrm{X}$ receptor, constitutive androstane receptor, and orphan nuclear receptor hepatocyte nuclear factor 4alpha in the regulation of human steroid-/bile acid-sulfotransferase. Mol Endocrinol 21 (9): 2099-2111.

Edwards PA, Kast HR, Anisfeld AM (2002). BAREing it all: the adoption of LXR and FXR and their roles in lipid homeostasis. J Lipid Res 43 (1): 2-12.

Ellis E, Wagner M, Lammert F, Nemeth A, Gumhold J, Strassburg CP et al. (2006). Successful treatment of severe unconjugated hyperbilirubinemia via induction of UGT1A1 by rifampicin. J Hepatol 44 (1): 243-245.

Eloranta JJ, Kullak-Ublick GA (2005). Coordinate transcriptional regulation of bile acid homeostasis and drug metabolism. Arch Biochem Biophys 433 (2): 397-412.

Eloranta JJ, Jung D, Kullak-Ublick GA (2006). The human Na+taurocholate cotransporting polypeptide gene is activated by glucocorticoid receptor and peroxisome proliferator-activated receptor-\{gamma\} coactivator- 1 \{alpha\}, and suppressed by bile acids via a small heterodimer partner-dependent mechanism. Mol Endocrinol 20 (1): 65-79.

Falany CN (1997). Enzymology of human cytosolic sulfotransferases. FASEB J 11 (4): 206-216.

Falkner KC, Pinaire JA, Xiao GH, Geoghegan TE, Prough RA (2001). Regulation of the rat glutathione S-transferase A2 gene by glucocorticoids: involvement of both the glucocorticoid and pregnane $\mathrm{X}$ receptors. Mol Pharmacol 60 (3): 611-619.

Fang HL, Strom SC, Cai H, Falany CN, Kocarek TA, Runge-Morris M (2005). Regulation of human hepatic hydroxysteroid sulfotransferase gene expression by the peroxisome proliferator-activated receptor alpha transcription factor. Mol Pharmacol 67 (4): 12571267.

Fayard E, Auwerx J, Schoonjans K (2004). LRH-1: an orphan nuclear receptor involved in development, metabolism and steroidogenesis. Trends Cell Biol 14 (5): 250-260.

Fickert P, Zollner G, Fuchsbichler A, Stumptner C, Pojer C, Zenz R et al. (2001). Effects of ursodeoxycholic and cholic acid feeding on hepatocellular transporter expression in mouse liver. Gastroenterology 121 (1): 170-183.

Fickert P, Zollner G, Fuchsbichler A, Stumptner C, Weiglein AH, Lammert F et al. (2002). Ursodeoxycholic acid aggravates bile infarcts in bile duct-ligated and Mdr2 knockout mice via disruption of cholangioles. Gastroenterology 123 (4): 1238-1251.

Finck BN, Kelly DP (2006). PGC-1 coactivators: inducible regulators of 
energy metabolism in health and disease. J Clin Invest 116 (3): 615-622.

Fiorucci S, Antonelli E, Rizzo G, Renga B, Mencarelli A, Riccardi L et al. (2004). The nuclear receptor SHP mediates inhibition of hepatic stellate cells by FXR and protects against liver fibrosis. Gastroenterology 127 (5): 1497-1512.

Fiorucci S, Clerici C, Antonelli E, Orlandi S, Goodwin B, Sadeghpour BM et al. (2005a). Protective effects of 6-ethyl chenodeoxycholic acid, a farnesoid $\mathrm{X}$ receptor ligand, in estrogen-induced cholestasis. J Pharmacol Exp Ther 313 (2): 604-612.

Fiorucci S, Rizzo G, Antonelli E, Renga B, Mencarelli A, Riccardi L et al. (2005b). Cross-talk between farnesoid-X-receptor (FXR) and peroxisome proliferator-activated receptor gamma contributes to the antifibrotic activity of FXR ligands in rodent models of liver cirrhosis. J Pharmacol Exp Ther 315 (1): 58-68.

Fiorucci S, Rizzo G, Antonelli E, Renga B, Mencarelli A, Riccardi L et al. (2005c). A farnesoid $x$ receptor-small heterodimer partner regulatory cascade modulates tissue metalloproteinase inhibitor- 1 and matrix metalloprotease expression in hepatic stellate cells and promotes resolution of liver fibrosis. J Pharmacol Exp Ther 314 (2): 584-595.

Frankenberg T, Rao A, Chen F, Haywood J, Shneider BL, Dawson PA (2006). Regulation of the mouse organic solute transporter alphabeta, Ostalpha-Ostbeta, by bile acids. Am J Physiol Gastrointest Liver Physiol 290 (5): G912-G922.

Frohling W, Stiehl A (1976). Bile salt glucuronides: identification and quantitative analysis in the urine of patients with cholestasis. Eur J Clin Invest 6: 67-74.

Funk C, Ponelle C, Scheuermann G, Pantze M (2001). Cholestatic potential of troglitazone as a possible factor contributing to troglitazone-induced hepatotoxicity: in vivo and in vitro interaction at the canalicular bile salt export pump (Bsep) in the rat. Mol Pharmacol 59 (3): 627-635.

Gall WE, Zawada G, Mojarrabi B, Tephly TR, Green MD, Coffman BL et al. (1999). Differential glucuronidation of bile acids, androgens and estrogens by human UGT1A3 and 2B7. I Steroid Biochem Mol Biol 70 (1-3): 101-108.

Galli A, Crabb DW, Ceni E, Salzano R, Mello T, Svegliati-Baroni G et al. (2002). Antidiabetic thiazolidinediones inhibit collagen synthesis and hepatic stellate cell activation in vivo and in vitro. Gastroenterology 122 (7): 1924-1940.

Gascon-Barre M, Demers C, Mirshahi A, Neron S, Zalzal S, Nanci A (2003). The normal liver harbors the vitamin D nuclear receptor in nonparenchymal and biliary epithelial cells. Hepatology 37 (5): 1034-1042.

Gerloff T, Geier A, Roots I, Meier PJ, Gartung C (2002). Functional analysis of the rat bile salt export pump gene promoter. Eur $J$ Biochem 269 (14): 3495-3503.

Ghisletti S, Huang W, Ogawa S, Pascual G, Lin ME, Willson TM et al. (2007). Parallel SUMOylation-dependent pathways mediate geneand signal-specific transrepression by LXRs and PPARgamma. Mol Cell 25 (1): 57-70.

Ghose R, Zimmerman TL, Thevananther S, Karpen SJ (2004). Endotoxin leads to rapid subcellular re-localization of hepatic RXRalpha: a novel mechanism for reduced hepatic gene expression in inflammation. Nucl Recept 2 (1): 4.

Ghose R, Mulder J, von Furstenberg RJ, Thevananther S, Kuipers F, Karpen SJ (2007). Rosiglitazone attenuates suppression of RXRalpha-dependent gene expression in inflamed liver. J Hepatol 46 (1): 115-123.

Glass CK, Rosenfeld MG (2000). The coregulator exchange in transcriptional functions of nuclear receptors. Genes Dev 14 (2): 121-141.

Gnerre C, Blattler S, Kaufmann MR, Looser R, Meyer UA (2004). Regulation of CYP3A4 by the bile acid receptor FXR: evidence for functional binding sites in the CYP3A4 gene. Pharmacogenetics 14 (10): 635-645.

Gong H, Singh SV, Singh SP, Mu Y, Lee JH, Saini SP et al. (2006).
Orphan nuclear receptor pregnane $\mathrm{X}$ receptor sensitizes oxidative stress responses in transgenic mice and cancerous cells. Mol Endocrinol 20 (2): 279-290.

Goodwin B, Moore JT (2004). CAR: detailing new models. Trends Pharmacol Sci 25 (8): 437-441.

Goodwin B, Jones SA, Price RR, Watson MA, McKee DD, Moore LB et al. (2000). A regulatory cascade of the nuclear receptors FXR, SHP-1, and LRH-1 represses bile acid biosynthesis. Mol Cell 6 (3): $517-526$.

Goodwin B, Hodgson E, D'Costa DJ, Robertson GR, Liddle C (2002a). Transcriptional regulation of the human CYP3A4 gene by the constitutive androstane receptor. Mol Pharmacol 62 (2): 359-365.

Goodwin B, Redinbo MR, Kliewer SA (2002b). Regulation of cyp3a gene transcription by the pregnane x receptor. Annu Rev Pharmacol Toxicol 42: 1-23.

Goodwin B, Watson MA, Kim H, Miao J, Kemper JK, Kliewer SA (2003). Differential regulation of rat and human CYP7A1 by the nuclear oxysterol receptor liver X receptor-alpha. Mol Endocrinol 17 (3): 386-394.

Guo GL, Lambert G, Negishi M, Ward JM, Brewer HB, Jr, Kliewer SA et al. (2003). Complementary roles of farnesoid X receptor, pregnane $\mathrm{X}$ receptor, and constitutive androstane receptor in protection against bile acid toxicity. J Biol Chem 278 (46): 45062-45071.

Handschin C, Meyer UA (2003). Induction of drug metabolism: the role of nuclear receptors. Pharmacol Rev 55 (4): 649-673.

Haughton EL, Tucker SJ, Marek CJ, Durward E, Leel V, Bascal Z et al. (2006). Pregnane X receptor activators inhibit human hepatic stellate cell transdifferentiation in vitro. Gastroenterology 131 (1): 194209.

Hertz R, Magenheim J, Berman I, Bar-Tana J (1998). Fatty acyl-CoA thioesters are ligands of hepatic nuclear factor-4alpha. Nature 392 (6675): 512-516.

Hirohashi T, Suzuki H, Ito K, Ogawa K, Kume K, Shimizu T et al. (1998). Hepatic expression of multidrug resistance-associated protein-like proteins maintained in eisai hyperbilirubinemic rats. Mol Pharmacol 53 (6): 1068-1075.

Holt JA, Luo G, Billin AN, Bisi J, McNeill YY, Kozarsky KF et al. (2003). Definition of a novel growth factor-dependent signal cascade for the suppression of bile acid biosynthesis. Genes Dev 17 (13): 1581-1591.

Honjo Y, Sasaki S, Kobayashi Y, Misawa H, Nakamura H (2006). 1,25-dihydroxyvitamin D3 and its receptor inhibit the chenodeoxycholic acid-dependent transactivation by farnesoid $\mathrm{X}$ receptor. J Endocrinol 188 (3): 635-643.

Hooiveld GJ, Vos TA, Scheffer GL, Van Goor H, Koning H, Bloks V et al. (1999). 3-Hydroxy-3-methylglutaryl-coenzyme A reductase inhibitors (statins) induce hepatic expression of the phospholipid translocase mdr2 in rats. Gastroenterology 117 (3): 678-687.

Huang L, Zhao A, Lew JL, Zhang T, Hrywna Y, Thompson JR et al. (2003a). Farnesoid $X$ receptor activates transcription of the phospholipid pump MDR3. J Biol Chem 278 (51): 51085-51090.

Huang W, Zhang J, Chua SS, Qatanani M, Han Y, Granata R et al. (2003b). Induction of bilirubin clearance by the constitutive androstane receptor (CAR). Proc Natl Acad Sci USA 100 (7): 4156-4161.

Huang W, Zhang J, Moore DD (2004). A traditional herbal medicine enhances bilirubin clearance by activating the nuclear receptor CAR. J Clin Invest 113 (1): 137-143.

Huang W, Zhang J, Washington M, Liu J, Parant JM, Lozano G et al. (2005). Xenobiotic stress induces hepatomegaly and liver tumors via the nuclear receptor constitutive androstane receptor. Mol Endocrinol 19 (6): 1646-1653.

Huang W, Ma K, Zhang J, Qatanani M, Cuvillier J, Liu J et al. (2006). Nuclear receptor-dependent bile acid signaling is required for normal liver regeneration. Science 312 (5771): 233-236.

Huss JM, Kasper CB (1998). Nuclear receptor involvement in the regulation of rat cytochrome P450 3A23 expression. J Biol Chem 273 (26): 16155-16162.

Inagaki T, Choi M, Moschetta A, Peng L, Cummins CL, McDonald JG 
et al. (2005). Fibroblast growth factor 15 functions as an enterohepatic signal to regulate bile acid homeostasis. Cell Metab 2 (4): 217-225.

Inagaki T, Moschetta A, Lee YK, Peng L, Zhao G, Downes $\mathrm{M}$ et al. (2006). Regulation of antibacterial defense in the small intestine by the nuclear bile acid receptor. Proc Natl Acad Sci USA 103 (10): 3920-3925.

Inokuchi A, Hinoshita E, Iwamoto Y, Kohno K, Kuwano M, Uchiumi $\mathrm{T}$ (2001). Enhanced expression of the human multidrug resistance protein 3 by bile salt in human enterocytes. A transcriptional control of a plausible bile acid transporter. J Biol Chem 276 (50): 46822-46829.

Janowski BA, Willy PJ, Devi TR, Falck JR, Mangelsdorf DJ (1996). An oxysterol signalling pathway mediated by the nuclear receptor LXR alpha. Nature 383 (6602): 728-731.

Joseph SB, Castrillo A, Laffitte BA, Mangelsdorf DJ, Tontonoz P (2003). Reciprocal regulation of inflammation and lipid metabolism by liver X receptors. Nat Med 9 (2): 213-219.

Jung D, Kullak-Ublick GA (2003). Hepatocyte nuclear factor 1 alpha: a key mediator of the effect of bile acids on gene expression. Hepatology 37 (3): 622-631.

Jung D, Fried M, Kullak-Ublick GA (2002). Human apical sodiumdependent bile salt transporter gene (SLC10A2) is regulated by the peroxisome proliferator-activated receptor alpha. J Biol Chem 277 (34): 30559-30566.

Jung D, Fantin AC, Scheurer U, Fried M, Kullak-Ublick GA (2004a). Human ileal bile acid transporter gene ASBT (SLC10A2) is transactivated by the glucocorticoid receptor. Gut 53 (1): 78-84.

Jung D, Hagenbuch B, Fried M, Meier PJ, Kullak-Ublick GA (2004b). Role of liver-enriched transcription factors and nuclear receptors in regulating the human, mouse, and rat NTCP gene. Am J Physiol Gastrointest Liver Physiol 286 (5): G752-G761.

Kamisako T, Adachi Y (1995). Marked improvement in cholestasis and hypercholesterolemia with simvastatin in a patient with primary biliary cirrhosis. Am J Gastroenterol 90 (7): 1187-1188.

Kamiya A, Inoue Y, Gonzalez FJ (2003). Role of the hepatocyte nuclear factor 4alpha in control of the pregnane $X$ receptor during fetal liver development. Hepatology 37 (6): 1375-1384.

Kanda T, Yokosuka O, Imazeki F, Saisho H (2003). Bezafibrate treatment: a new medical approach for PBC patients? J Gastroenterol 38 (6): 573-578.

Karpen SJ (2002). Nuclear receptor regulation of hepatic function. J Hepatol 36 (6): 832-850.

Karpen SJ (2005). Exercising the nuclear option to treat cholestasis: CAR and PXR ligands. Hepatology 42 (2): 266-269.

Karpen SJ, Sun AQ, Kudish B, Hagenbuch B, Meier PJ, Ananthanarayanan $\mathrm{M}$ et al. (1996). Multiple factors regulate the rat liver basolateral sodium-dependent bile acid cotransporter gene promoter. J Biol Chem 271 (25): 15211-15221.

Kast HR, Goodwin B, Tarr PT, Jones SA, Anisfeld AM, Stoltz CM et al. (2002). Regulation of multidrug resistance-associated protein 2 (ABCC2) by the nuclear receptors pregnane $\mathrm{X}$ receptor, farnesoid $\mathrm{X}$-activated receptor, and constitutive androstane receptor. J Biol Chem 277 (4): 2908-2915.

Keitel V, Burdelski M, Warskulat U, Kuhlkamp T, Keppler D, Haussinger D et al. (2005). Expression and localization of hepatobiliary transport proteins in progressive familial intrahepatic cholestasis. Hepatology 41 (5): 1160-1172.

Kim HI, Koh YK, Kim TH, Kwon SK, Im SS, Choi HS et al. (2007a). Transcriptional activation of SHP by PPAR-gamma in liver. Biochem Biophys Res Commun 360 (2): 301-306.

Kim I, Ahn SH, Inagaki T, Choi M, Ito S, Guo GL et al. (2007b). Differential regulation of bile acid homeostasis by the farnesoid $\mathrm{X}$ receptor in liver and intestine. J Lipid Res 48 (12): 2664-2672.

Kim I, Morimura K, Shah Y, Yang Q, Ward JM, Gonzalez FJ (2007c). Spontaneous hepatocarcinogenesis in farnesoid $\mathrm{X}$ receptor-null mice. Carcinogenesis 28 (5): 940-946.
Kim MS, Shigenaga J, Moser A, Feingold K, Grunfeld C (2003). Repression of farnesoid $\mathrm{X}$ receptor during the acute phase response. J Biol Chem 278 (11): 8988-8995.

King CD, Rios GR, Green MD, Tephly TR (2000). UDPglucuronosyltransferases. Curr Drug Metab 1 (2): 143-161.

Kok T, Bloks VW, Wolters H, Havinga R, Jansen PL, Staels B et al. (2003). Peroxisome proliferator-activated receptor alpha (PPARalpha)-mediated regulation of multidrug resistance 2 (Mdr2) expression and function in mice. Biochem J 369 (Pt 3): 539-547.

Kota BP, Huang TH, Roufogalis BD (2005). An overview on biological mechanisms of PPARs. Pharmacol Res 51 (2): 85-94.

Krylova IN, Sablin EP, Moore J, Xu RX, Waitt GM, MacKay JA et al. (2005). Structural analyses reveal phosphatidyl inositols as ligands for the NR5 orphan receptors SF-1 and LRH-1. Cell 120 (3): 343-355.

Kubitz R, Wettstein M, Warskulat U, Haussinger D (1999). Regulation of the multidrug resistance protein 2 in the rat liver by lipopolysaccharide and dexamethasone. Gastroenterology 116 (2): 401-410.

Kullak-Ublick GA, Stieger B, Hagenbuch B, Meier PJ (2000). Hepatic transport of bile salts. Semin Liver Dis 20 (3): 273-292.

Kumar R, Johnson BH, Thompson EB (2004). Overview of the structural basis for transcription regulation by nuclear hormone receptors. Essays Biochem 40: 27-39.

Kurihara T, Akimoto M, Abe K, Ishiguro H, Niimi A, Maeda A et al. (1993). Experimental use of pravastatin in patients with primary biliary cirrhosis associated with hypercholesterolemia. Clin Ther 15 (5): 890-898.

Kurihara T, Niimi A, Maeda A, Shigemoto M, Yamashita K (2000). Bezafibrate in the treatment of primary biliary cirrhosis: comparison with ursodeoxycholic acid. Am J Gastroenterol 95 (10): 29902992.

Kurihara T, Maeda A, Shigemoto M, Yamashita K, Hashimoto E (2002). Investigation into the efficacy of bezafibrate against primary biliary cirrhosis, with histological references from cases receiving long term monotherapy. Am J Gastroenterol 97 (1): 212-214.

Ladias JA, Hadzopoulou-Cladaras M, Kardassis D, Cardot P, Cheng J, Zannis V et al. (1992). Transcriptional regulation of human apolipoprotein genes ApoB, ApoCIII, and ApoAII by members of the steroid hormone receptor superfamily HNF-4, ARP-1, EAR-2, and EAR-3. J Biol Chem 267 (22): 15849-15860.

Laffitte BA, Tontonoz P (2002). Orphan nuclear receptors find a home in the arterial wall. Curr Atheroscler Rep 4 (3): 213-221.

Laffitte BA, Kast HR, Nguyen CM, Zavacki AM, Moore DD, Edwards PA (2000). Identification of the DNA binding specificity and potential target genes for the farnesoid X-activated receptor. J Biol Chem 275 (14): 10638-10647.

Landrier JF, Thomas C, Grober J, Duez H, Percevault F, Souidi M et al. (2004). Statin induction of liver fatty acid-binding protein (L-FABP) gene expression is peroxisome proliferator-activated receptoralpha-dependent. J Biol Chem 279 (44): 45512-45518.

Landrier JF, Eloranta JJ, Vavricka SR, Kullak-Ublick GA (2006). The nuclear receptor for bile acids, FXR, transactivates human organic solute transporter-alpha and -beta genes. Am J Physiol Gastrointest Liver Physiol 290 (3): G476-G485.

Lee FY, Lee H, Hubbert ML, Edwards PA, Zhang Y (2006a). FXR, a multipurpose nuclear receptor. Trends Biochem Sci 31 (10): 572580.

Lee H, Zhang Y, Lee FY, Nelson SF, Gonzalez FJ, Edwards PA (2006b). FXR regulates organic solute transporter alpha and beta in the adrenal gland, kidney and intestine. J Lipid Res 47: 201-214.

Lee WM (2003). Drug-induced hepatotoxicity. N Engl J Med 349 (5): 474-485.

Lee YK, Dell H, Dowhan DH, Hadzopoulou-Cladaras M, Moore DD (2000). The orphan nuclear receptor SHP inhibits hepatocyte nuclear factor 4 and retinoid $\mathrm{X}$ receptor transactivation: two mechanisms for repression. Mol Cell Biol 20 (1): 187-195.

Lee YK, Schmidt DR, Cummins CL, Choi M, Peng L, Zhang Y et al. (2008). Liver receptor homolog-1 regulates bile acid homeostasis 
but is not essential for feedback regulation of bile acid synthesis. Mol Endocrinol 2008 (6): 1345-1356.

Lehmann JM, Kliewer SA, Moore LB, Smith-Oliver TA, Oliver BB, Su JL et al. (1997). Activation of the nuclear receptor LXR by oxysterols defines a new hormone response pathway. J Biol Chem 272 (6): 3137-3140.

Lehmann JM, McKee DD, Watson MA, Willson TM, Moore JT, Kliewer SA (1998). The human orphan nuclear receptor PXR is activated by compounds that regulate CYP3A4 gene expression and cause drug interactions. J Clin Invest 102 (5): 1016-1023.

Leuschner M, Guldutuna S, You T, Hubner K, Bhatti S, Leuschner U (1996). Ursodeoxycholic acid and prednisolone versus ursodeoxycholic acid and placebo in the treatment of early stages of primary biliary cirrhosis. J Hepatol 25 (1): 49-57.

Leuschner M, Maier KP, Schlichting J, Strahl S, Herrmann G, Dahm HH et al. (1999). Oral budesonide and ursodeoxycholic acid for treatment of primary biliary cirrhosis: results of a prospective double-blind trial. Gastroenterology 117 (4): 918-925.

Lew JL, Zhao A, Yu J, Huang L, De Pedro N, Pelaez F et al. (2004). The farnesoid $X$ receptor controls gene expression in a ligand- and promoter-selective fashion. J Biol Chem 279 (10): 8856-8861.

Li D, Zimmerman TL, Thevananther S, Lee HY, Kurie JM, Karpen SJ (2002). Interleukin-1 beta-mediated suppression of RXR : RAR transactivation of the Ntcp promoter is JNK-dependent. J Biol Chem 277 (35): 31416-31422.

Li J, Ning G, Duncan SA (2000). Mammalian hepatocyte differentiation requires the transcription factor HNF-4alpha. Genes Dev 14 (4): 464-474.

Li T, Chiang JY (2005). Mechanism of rifampicin and pregnane X receptor inhibition of human cholesterol 7 alpha-hydroxylase gene transcription. Am J Physiol Gastrointest Liver Physiol 288 (1): G74G84.

Lu TT, Makishima M, Repa JJ, Schoonjans K, Kerr TA, Auwerx J et al. (2000). Molecular basis for feedback regulation of bile acid synthesis by nuclear receptors. Mol Cell 6 (3): 507-515.

Lu TT, Repa JJ, Mangelsdorf DJ (2001). Orphan nuclear receptors as eLiXiRs and FiXeRs of sterol metabolism. J Biol Chem 276 (41): 37735-37738.

Lutjohann D, Hahn C, Prange W, Sudhop T, Axelson M, Sauerbruch T et al. (2004). Influence of rifampin on serum markers of cholesterol and bile acid synthesis in men. Int J Clin Pharmacol Ther 42 (6): 307-313.

McCarthy TC, Li X, Sinal CJ (2005). Vitamin D receptor-dependent regulation of colon multidrug resistance-associated protein 3 gene expression by bile acids. J Biol Chem 280 (24): 23232-23242.

McKenna NJ, Lanz RB, O'Malley BW (1999). Nuclear receptor coregulators: cellular and molecular biology. Endocr Rev 20 (3): 321-344.

Maher JM, Cheng X, Slitt AL, Dieter MZ, Klaassen CD (2005). Induction of the multidrug resistance-associated protein family of transporters by chemical activators of receptor-mediated pathways in mouse liver. Drug Metab Dispos 33 (7): 956-962.

Makino I, Hashimoto H, Shinozaki K, Yoshino K, Nakagawa S (1975). Sulfated and nonsulfated bile acids in urine, serum, and bile of patients with hepatobiliary diseases. Gastroenterology 68 (3): 545553.

Makishima M, Lu TT, Xie W, Whitfield GK, Domoto H, Evans RM et al. (2002). Vitamin D receptor as an intestinal bile acid sensor. Science 296 (5571): 1313-1316.

Mangelsdorf DJ, Evans RM (1995). The RXR heterodimers and orphan receptors. Cell 83 (6): 841-850.

Marek CJ, Tucker SJ, Konstantinou DK, Elrick LJ, Haefner D, Sigalas C et al. (2005). Pregnenolone-16alpha-carbonitrile inhibits rodent liver fibrogenesis via PXR (pregnane $X$ receptor)-dependent and PXR-independent mechanisms. Biochem J 387 (Pt 3): 601-608.

Marra F, DeFranco R, Robino G, Novo E, Efsen E, Pastacaldi S et al. (2005). Thiazolidinedione treatment inhibits bile duct proliferation and fibrosis in a rat model of chronic cholestasis. World J Gastroenterol 11 (32): 4931-4938.

Marrapodi M, Chiang JY (2000). Peroxisome proliferator-activated receptor alpha (PPARalpha) and agonist inhibit cholesterol 7alphahydroxylase gene (CYP7A1) transcription. J Lipid Res 41 (4): 514-520.

Marschall HU, Wagner M, Zollner G, Fickert P, Diczfalusy U, Gumhold $\mathrm{J}$ et al. (2005). Complementary stimulation of hepatobiliary transport and detoxification systems by rifampicin and ursodeoxycholic acid in humans. Gastroenterology 129 (2): 476-485.

Marschall HU, Wagner M, Bodin K, Zollner G, Fickert P, Gumhold J et al. (2006). $\operatorname{Fxr}(-/-)$ mice adapt to biliary obstruction by enhanced phase I detoxification and renal elimination of bile acids. J Lipid Res 47 (3): 582-592.

Mataki C, Magnier BC, Houten SM, Annicotte JS, Argmann C, Thomas C et al. (2007). Compromised intestinal lipid absorption in mice with a liver-specific deficiency of liver receptor homolog 1. Mol Cell Biol 27 (23): 8330-8339.

Matsumura K, Saito T, Takahashi Y, Ozeki T, Kiyotani K, Fujieda M et al. (2004). Identification of a novel polymorphic enhancer of the human CYP3A4 gene. Mol Pharmacol 65 (2): 326-334.

Miquerol L, Lopez S, Cartier N, Tulliez M, Raymondjean M, Kahn A (1994). Expression of the L-type pyruvate kinase gene and the hepatocyte nuclear factor 4 transcription factor in exocrine and endocrine pancreas. J Biol Chem 269 (12): 8944-8951.

Miranda S, Vollrath V, Wielandt AM, Loyola G, Bronfman M, Chianale J (1997). Overexpression of mdr2 gene by peroxisome proliferators in the mouse liver. J Hepatol 26 (6): 1331-1339.

Mitchison HC, Palmer JM, Bassendine MF, Watson AJ, Record CO, James OF (1992). A controlled trial of prednisolone treatment in primary biliary cirrhosis. Three-year results. J Hepatol 15 (3): 336-344.

Miura N, Tanaka K (1993). Analysis of the rat hepatocyte nuclear factor (HNF) 1 gene promoter: synergistic activation by HNF4 and HNF1 proteins. Nucleic Acids Res 21 (16): 3731-3736.

Miura T, Ouchida R, Yoshikawa N, Okamoto K, Makino Y, Nakamura $\mathrm{T}$ et al. (2001). Functional modulation of the glucocorticoid receptor and suppression of NF-kappaB-dependent transcription by ursodeoxycholic acid. J Biol Chem 276 (50): 47371-47378.

Moreau A, Vilarem MJ, Maurel P, Pascussi JM (2008). Xenoreceptors CAR and PXR activation and consequences on lipid metabolism, glucose homeostasis, and inflammatory response. Mol Pharm 5 (1): 35-41.

Moschetta A, Bookout AL, Mangelsdorf DJ (2004). Prevention of cholesterol gallstone disease by FXR agonists in a mouse model. Nat Med 10 (12): 1352-1358.

Myant NB, Mitropoulos KA (1977). Cholesterol 7 alpha-hydroxylase. J Lipid Res 18 (2): 135-153.

Nakai S, Masaki T, Kurokohchi K, Deguchi A, Nishioka M (2000). Combination therapy of bezafibrate and ursodeoxycholic acid in primary biliary cirrhosis: a preliminary study. Am J Gastroenterol 95 (1): 326-327.

Nakata K, Tanaka Y, Nakano T, Adachi T, Tanaka H, Kaminuma T et al. (2006). Nuclear receptor-mediated transcriptional regulation in Phase I, II, and III xenobiotic metabolizing systems. Drug Metab Pharmacokinet 21 (6): 437-457.

Nishihara E, O'Malley BW, Xu J (2004). Nuclear receptor coregulators are new players in nervous system development and function. Mol Neurobiol 30 (3): 307-325.

Nishimura M, Koeda A, Suzuki E, Kawano Y, Nakayama M, Satoh T et al. (2006). Regulation of mRNA expression of MDR1, MRP1, MRP2 and MRP3 by prototypical microsomal enzyme inducers in primary cultures of human and rat hepatocytes. Drug Metab Pharmacokinet 21 (4): 297-307.

Nitta M, Ku S, Brown C, Okamoto AY, Shan B (1999). CPF: an orphan nuclear receptor that regulates liver-specific expression of the human cholesterol 7alpha-hydroxylase gene. Proc Natl Acad Sci USA 96 (12): 6660-6665.

Odom DT, Zizlsperger N, Gordon DB, Bell GW, Rinaldi NJ, Murray HL 
et al. (2004). Control of pancreas and liver gene expression by HNF transcription factors. Science 303 (5662): 1378-1381.

Ogawa K, Suzuki H, Hirohashi T, Ishikawa T, Meier PJ, Hirose K et al. (2000). Characterization of inducible nature of MRP3 in rat liver. Am J Physiol Gastrointest Liver Physiol 278 (3): G438-G446.

Ogino M, Nagata K, Miyata M, Yamazoe Y (1999). Hepatocyte nuclear factor 4-mediated activation of rat CYP3A1 gene and its modes of modulation by apolipoprotein AI regulatory protein I and v-ErbArelated protein 3. Arch Biochem Biophys 362 (1): 32-37.

Ohmoto K, Mitsui Y, Yamamoto S (2001). Effect of bezafibrate in primary biliary cirrhosis: a pilot study. Liver 21 (3): 223-224

Oiwa A, Kakizawa T, Miyamoto T, Yamashita K, Jiang W, Takeda T et al. (2007). Synergistic regulation of the mouse orphan nuclear receptor SHP gene promoter by CLOCK-BMAL1 and LRH-1. Biochem Biophys Res Commun 353 (4): 895-901.

Ortlund EA, Lee Y, Solomon IH, Hager JM, Safi R, Choi Y et al. (2005). Modulation of human nuclear receptor LRH-1 activity by phospholipids and SHP. Nat Struct Mol Biol 12 (4): 357-363.

Ou J, Tu H, Shan B, Luk A, DeBose-Boyd RA, Bashmakov Y et al. (2001). Unsaturated fatty acids inhibit transcription of the sterol regulatory element-binding protein-1c (SREBP-1c) gene by antagonizing ligand-dependent activation of the LXR. Proc Natl Acad Sci USA 98 (11): 6027-6032.

Oude Elferink RP, Paulusma CC, Groen AK (2006). Hepatocanalicular transport defects: pathophysiologic mechanisms of rare diseases. Gastroenterology 130 (3): 908-925.

Parks DJ, Blanchard SG, Bledsoe RK, Chandra G, Consler TG, Kliewer SA et al. (1999). Bile acids: natural ligands for an orphan nuclear receptor. Science 284 (5418): 1365-1368.

Pascual G, Fong AL, Ogawa S, Gamliel A, Li AC, Perissi V et al. (2005). A SUMOylation-dependent pathway mediates transrepression of inflammatory response genes by PPAR-gamma. Nature 437 (7059): 759-763.

Pascussi JM, Drocourt L, Fabre JM, Maurel P, Vilarem MJ (2000). Dexamethasone induces pregnane $\mathrm{X}$ receptor and retinoid $\mathrm{X}$ receptor-alpha expression in human hepatocytes: synergistic increase of CYP3A4 induction by pregnane $\mathrm{X}$ receptor activators. Mol Pharmacol 58 (2): 361-372.

Pascussi JM, Gerbal-Chaloin S, Drocourt L, Maurel P, Vilarem MJ (2003). The expression of CYP2B6, CYP2C9 and CYP3A4 genes: a tangle of networks of nuclear and steroid receptors. Biochim Biophys Acta 1619 (3): 243-253.

Patel DD, Knight BL, Soutar AK, Gibbons GF, Wade DP (2000). The effect of peroxisome-proliferator-activated receptor-alpha on the activity of the cholesterol 7 alpha-hydroxylase gene. Biochem J 351 (Pt 3): 747-753.

Paumgartner G, Pusl T (2008). Medical treatment of cholestatic liver disease. Clin Liver Dis 12 (1): 53-80.

Pellicciari R, Costantino G, Fiorucci S (2005). Farnesoid X receptor: from structure to potential clinical applications. J Med Chem 48 (17): 5383-5403.

Pellicoro A, Faber KN (2007). Review article: the function and regulation of proteins involved in bile salt biosynthesis and transport. Aliment Pharmacol Ther 26 (Suppl. 2): 149-160.

Perissi V, Rosenfeld MG (2005). Controlling nuclear receptors: the circular logic of cofactor cycles. Nat Rev Mol Cell Biol 6 (7): 542-554.

Pikuleva IA, Babiker A, Waterman MR, Bjorkhem I (1998). Activities of recombinant human cytochrome P450c27 (CYP27) which produce intermediates of alternative bile acid biosynthetic pathways. $J$ Biol Chem 273 (29): 18153-18160.

Pineda TI, Claudel T, Duval C, Kosykh V, Fruchart JC, Staels B (2003). Bile acids induce the expression of the human peroxisome proliferator-activated receptor alpha gene via activation of the farnesoid X receptor. Mol Endocrinol 17 (2): 259-272.

Pineda Torra I, Jamshidi Y, Flavell DM, Fruchart JC, Staels B (2002). Characterization of the human PPARalpha promoter: identification of a functional nuclear receptor response element. Mol Endocrinol 16 (5): 1013-1028.

Plass JR, Mol O, Heegsma J, Geuken M, Faber KN, Jansen PL et al. (2002). Farnesoid X receptor and bile salts are involved in transcriptional regulation of the gene encoding the human bile salt export pump. Hepatology 35 (3): 589-596.

Post SM, Duez H, Gervois PP, Staels B, Kuipers F, Princen HM (2001). Fibrates suppress bile acid synthesis via peroxisome proliferatoractivated receptor-alpha-mediated downregulation of cholesterol 7alpha-hydroxylase and sterol 27-hydroxylase expression. Arterioscler Thromb Vasc Biol 21 (11): 1840-1845.

Prieto J, Qian C, Garcia N, Diez J, Medina JF (1993). Abnormal expression of anion exchanger genes in primary biliary cirrhosis. Gastroenterology 105 (2): 572-578.

Prince MI, Burt AD, Jones DE (2002). Hepatitis and liver dysfunction with rifampicin therapy for pruritus in primary biliary cirrhosis. Gut 50 (3): 436-439.

Pulaski L, Kania K, Ratajewski M, Uchiumi T, Kuwano M, Bartosz G (2005). Differential regulation of the human MRP2 and MRP3 gene expression by glucocorticoids. J Steroid Biochem Mol Biol 96 (3-4): 229-234.

Rautiainen H, Karkkainen P, Karvonen AL, Nurmi H, Pikkarainen P, Nuutinen $\mathrm{H}$ et al. (2005). Budesonide combined with UDCA to improve liver histology in primary biliary cirrhosis: a three-year randomized trial. Hepatology 41 (4): 747-752.

Repa JJ, Berge KE, Pomajzl C, Richardson JA, Hobbs H, Mangelsdorf DJ (2002). Regulation of ATP-binding cassette sterol transporters ABCG5 and ABCG8 by the liver X receptors alpha and beta. J Biol Chem 277 (21): 18793-18800.

Ritzel U, Leonhardt U, Nather M, Schafer G, Armstrong VW, Ramadori $G$ (2002). Simvastatin in primary biliary cirrhosis: effects on serum lipids and distinct disease markers. J Hepatol 36 (4): 454-458.

Roglans N, Vazquez-Carrera M, Alegret M, Novell F, Zambon D, Ros E et al. (2004). Fibrates modify the expression of key factors involved in bile-acid synthesis and biliary-lipid secretion in gallstone patients. Eur J Clin Pharmacol 59 (12): 855-861.

Rudling M, Angelin B, Stahle L, Reihner E, Sahlin S, Olivecrona H et al. (2002). Regulation of hepatic low-density lipoprotein receptor, 3-hydroxy-3-methylglutaryl coenzyme A reductase, and cholesterol 7alpha-hydroxylase mRNAs in human liver. J Clin Endocrinol Metab 87 (9): 4307-4313.

Runge-Morris M, Wu W, Kocarek TA (1999). Regulation of rat hepatic hydroxysteroid sulfotransferase (SULT2-40/41) gene expression by glucocorticoids: evidence for a dual mechanism of transcriptional control. Mol Pharmacol 56 (6): 1198-1206.

Saini SP, Sonoda J, Xu L, Toma D, Uppal H, Mu Y et al. (2004). A novel constitutive androstane receptor-mediated and CYP3Aindependent pathway of bile acid detoxification. Mol Pharmacol 65 (2): 292-300.

Saini SP, Mu Y, Gong H, Toma D, Uppal H, Ren S et al. (2005). Dual role of orphan nuclear receptor pregnane $\mathrm{X}$ receptor in bilirubin detoxification in mice. Hepatology 41 (3): 497-505.

Scholtes C, Diaz O, Icard V, Kaul A, Bartenschlager R, Lotteau V et al. (2008). Enhancement of genotype 1 hepatitis $C$ virus replication by bile acids through FXR. J Hepatol 48 (2): 192-199.

Schuetz EG, Strom S, Yasuda K, Lecureur V, Assem M, Brimer C et al. (2001). Disrupted bile acid homeostasis reveals an unexpected interaction among nuclear hormone receptors, transporters, and cytochrome P450. J Biol Chem 276 (42): 39411-39418.

Shih DQ, Bussen M, Sehayek E, Ananthanarayanan M, Shneider BL, Suchy FJ et al. (2001). Hepatocyte nuclear factor-1alpha is an essential regulator of bile acid and plasma cholesterol metabolism. Nat Genet 27 (4): 375-382.

Shoda J, Tanaka N, Osuga T, Matsuura K, Miyazaki H (1990). Altered bile acid metabolism in liver disease: concurrent occurrence of C-1 and C-6 hydroxylated bile acid metabolites and their preferential excretion into urine. J Lipid Res 31 (2): 249-259. 
Shoda J, Kano M, Oda K, Kamiya J, Nimura Y, Suzuki H et al. (2001). The expression levels of plasma membrane transporters in the cholestatic liver of patients undergoing biliary drainage and their association with the impairment of biliary secretory function. Am J Gastroenterol 96 (12): 3368-3378.

Shoda J, Inada Y, Tsuji A, Kusama H, Ueda T, Ikegami T et al. (2004). Bezafibrate stimulates canalicular localization of NBD-labeled PC in HepG2 cells by PPARalpha-mediated redistribution of ABCB4. J Lipid Res 45 (10): 1813-1825.

Sinal CJ, Tohkin M, Miyata M, Ward JM, Lambert G, Gonzalez FJ (2000). Targeted disruption of the nuclear receptor FXR/BAR impairs bile acid and lipid homeostasis. Cell 102 (6): 731-744.

Sladek FM (1994). Hepatocyte Nuclear Factor 4. R.G. Landes Company, Austin, TX.

Sladek FM, Zhong WM, Lai E, Darnell JE, Jr. (1990). Liver-enriched transcription factor HNF-4 is a novel member of the steroid hormone receptor superfamily. Genes Dev 4 (12B): 2353-2365.

Snow KL, Moseley RH (2007). Effect of thiazolidinediones on bile acid transport in rat liver. Life Sci 80 (8): 732-740.

Song C, Hiipakka RA, Liao S (2000). Selective activation of liver X receptor alpha by 6alpha-hydroxy bile acids and analogs. Steroids 65 (8): 423-427.

Song CS, Echchgadda I, Baek BS, Ahn SC, Oh T, Roy AK et al. (2001). Dehydroepiandrosterone sulfotransferase gene induction by bile acid activated farnesoid X receptor. J Biol Chem 276 (45): 4254942556.

Song X, Kaimal R, Yan B, Deng R (2008). Liver receptor homolog 1 transcriptionally regulates human bile salt export pump expression. J Lipid Res (5): 973-984.

Sonoda J, Xie W, Rosenfeld JM, Barwick JL, Guzelian PS, Evans RM (2002). Regulation of a xenobiotic sulfonation cascade by nuclear pregnane X receptor (PXR). Proc Natl Acad Sci USA 99 (21): 1380113806.

Soroka CJ, Lee JM, Azzaroli F, Boyer JL (2001). Cellular localization and up-regulation of multidrug resistance-associated protein 3 in hepatocytes and cholangiocytes during obstructive cholestasis in rat liver. Hepatology 33 (4): 783-791.

Squires EJ, Sueyoshi T, Negishi M (2004). Cytoplasmic localization of pregnane $\mathrm{X}$ receptor and ligand-dependent nuclear translocation in mouse liver. J Biol Chem 279 (47): 49307-49314.

Staudinger J, Liu Y, Madan A, Habeebu S, Klaassen CD (2001a). Coordinate regulation of xenobiotic and bile acid homeostasis by pregnane X receptor. Drug Metab Dispos 29 (11): 1467-1472.

Staudinger JL (2008). Liver-enriched nuclear receptors: therapeutic opportunities. Mol Pharm 5 (1): 1-2.

Staudinger JL, Goodwin B, Jones SA, Hawkins-Brown D, MacKenzie KI, LaTour A et al. (2001b). The nuclear receptor PXR is a lithocholic acid sensor that protects against liver toxicity. Proc Natl Acad Sci USA 98 (6): 3369-3374.

Stedman C, Robertson G, Coulter S, Liddle C (2004). Feed-forward regulation of bile acid detoxification by CYP3A4: studies in humanized transgenic mice. J Biol Chem 279 (12): 11336-11343.

Stedman C, Liddle C, Coulter S, Sonoda J, Alvarez JG, Evans RM et al. (2006). Benefit of farnesoid $\mathrm{X}$ receptor inhibition in obstructive cholestasis. Proc Natl Acad Sci USA 103 (30): 1132311328.

Stiehl A, Thaler MM, Admirand WH (1972). The effects of phenobarbital on bile salts and bilirubin in patients with intrahepatic and extrahepatic cholestasis. N Engl J Med 286 (16): 858-861.

Stojakovic T, Putz-Bankuti C, Fauler G, Scharnagl H, Wagner M, Stadlbauer V et al. (2007). Atorvastatin in patients with primary biliary cirrhosis and incomplete biochemical response to ursodeoxycholic acid. Hepatology 46 (3): 776-784.

Strautnieks SS, Bull LN, Knisely AS, Kocoshis SA, Dahl N, Arnell H et al. (1998). A gene encoding a liver-specific ABC transporter is mutated in progressive familial intrahepatic cholestasis. Nat Genet 20 (3): 233-238.
Stroup D, Crestani M, Chiang JY (1997). Identification of a bile acid response element in the cholesterol 7 alpha-hydroxylase gene CYP7A. Am J Physiol 273 (2 Pt 1): G508-G517.

Szatmari I, Vamosi G, Brazda P, Balint BL, Benko S, Szeles L et al. (2006). Peroxisome proliferator-activated receptor gammaregulated ABCG2 expression confers cytoprotection to human dendritic cells. J Biol Chem 281 (33): 23812-23823.

Takeda K, Ichiki T, Tokunou T, Funakoshi Y, Iino N, Hirano K et al. (2000). Peroxisome proliferator-activated receptor gamma activators downregulate angiotensin II type 1 receptor in vascular smooth muscle cells. Circulation 102 (15): 1834-1839.

Tall AR, Costet P, Luo Y (2000). Orphans' meet cholesterol. Nat Med 6 (10): 1104-1105.

Tanaka H, Makino I (1992). Ursodeoxycholic acid-dependent activation of the glucocorticoid receptor. Biochem Biophys Res Commun 188 (2): 942-948.

Tanaka Y, Kobayashi Y, Gabazza EC, Higuchi K, Kamisako T, Kuroda M et al. (2002). Increased renal expression of bilirubin glucuronide transporters in a rat model of obstructive jaundice. Am J Physiol Gastrointest Liver Physiol 282 (4): G656-G662.

Teng S, Piquette-Miller M (2005). The involvement of the pregnane X receptor in hepatic gene regulation during inflammation in mice. J Pharmacol Exp Ther 312 (2): 841-848.

Teng S, Piquette-Miller M (2007). Hepatoprotective role of PXR activation and MRP3 in cholic acid-induced cholestasis. Br J Pharmacol 151 (3): 367-376.

Teng S, Jekerle V, Piquette-Miller M (2003). Induction of ABCC3 (MRP3) by pregnane X receptor activators. Drug Metab Dispos 31 (11): 1296-1299.

Thomassen PA (1979). Urinary bile acids in late pregnancy and in recurrent cholestasis of pregnancy. Eur J Clin Invest 9 (6): 425-432.

Tian JM, Schibler U (1991). Tissue-specific expression of the gene encoding hepatocyte nuclear factor 1 may involve hepatocyte nuclear factor 4. Genes Dev 5 (12A): 2225-2234.

Tirona RG, Kim RB (2005). Nuclear receptors and drug disposition gene regulation. J Pharm Sci 94 (6): 1169-1186.

Tirona RG, Lee W, Leake BF, Lan LB, Cline CB, Lamba V et al. (2003). The orphan nuclear receptor HNF4alpha determines PXR- and CAR-mediated xenobiotic induction of CYP3A4. Nat Med 9 (2): 220-224

Trauner M, Boyer JL (2003). Bile salt transporters: molecular characterization, function, and regulation. Physiol Rev 83 (2): 633-671.

Trauner M, Meier PJ, Boyer JL (1998). Molecular pathogenesis of cholestasis. N Engl J Med 339 (17): 1217-1227.

Trottier J, Verreault M, Grepper S, Monte D, Belanger J, Kaeding J et al. (2006). Human UDP-glucuronosyltransferase (UGT)1A3 enzyme conjugates chenodeoxycholic acid in the liver. Hepatology 44 (5): $1158-1170$.

Turncliff RZ, Meier PJ, Brouwer KL (2004). Effect of dexamethasone treatment on the expression and function of transport proteins in sandwich-cultured rat hepatocytes. Drug Metab Dispos 32 (8): 834839.

Turunen MM, Dunlop TW, Carlberg C, Vaisanen S (2007). Selective use of multiple vitamin $\mathrm{D}$ response elements underlies the 1 alpha,25-dihydroxyvitamin D3-mediated negative regulation of the human CYP27B1 gene. Nucleic Acids Res 35 (8): 2734-2747.

Uppal H, Toma D, Saini SP, Ren S, Jones TJ, Xie W (2005). Combined loss of orphan receptors PXR and CAR heightens sensitivity to toxic bile acids in mice. Hepatology 41 (1): 168-176.

Uppal H, Saini SP, Moschetta A, Mu Y, Zhou J, Gong H et al. (2007). Activation of LXRs prevents bile acid toxicity and cholestasis in female mice. Hepatology 45 (2): 422-432.

Van Mil SW, Milona A, Dixon PH, Mullenbach R, Geenes VL, Chambers J et al. (2007). Functional variants of the central bile acid sensor FXR identified in intrahepatic cholestasis of pregnancy. Gastroenterology 133 (2): 507-516.

Verreault M, Senekeo-Effenberger K, Trottier J, Bonzo JA, Belanger J, 
Kaeding J et al. (2006). The liver X-receptor alpha controls hepatic expression of the human bile acid-glucuronidating UGT1A3 enzyme in human cells and transgenic mice. Hepatology 44 (2): 368-378.

Wagner M, Fickert P, Zollner G, Fuchsbichler A, Silbert D, Tsybrovskyy $\mathrm{O}$ et al. (2003). Role of farnesoid $\mathrm{X}$ receptor in determining hepatic $\mathrm{ABC}$ transporter expression and liver injury in bile duct-ligated mice. Gastroenterology 125 (3): 825-838.

Wagner M, Halilbasic E, Marschall HU, Zollner G, Fickert P, Langner C et al. (2005). CAR and PXR agonists stimulate hepatic bile acid and bilirubin detoxification and elimination pathways in mice. Нераtology 42 (2): 420-430.

Wang B, Cai SR, Gao C, Sladek FM, Ponder KP (2001). Lipopolysaccharide results in a marked decrease in hepatocyte nuclear factor 4 alpha in rat liver. Hepatology 34 (5): 979-989.

Wang L, Lee YK, Bundman D, Han Y, Thevananther S, Kim CS et al. (2002). Redundant pathways for negative feedback regulation of bile acid production. Dev Cell 2 (6): 721-731.

Wang W, Zhang C, Marimuthu A, Krupka HI, Tabrizizad M, Shelloe R et al. (2005). The crystal structures of human steroidogenic factor-1 and liver receptor homologue-1. Proc Natl Acad Sci USA 102 (21): 7505-7510.

Warskulat U, Kubitz R, Wettstein M, Stieger B, Meier PJ, Haussinger D (1999). Regulation of bile salt export pump mRNA levels by dexamethasone and osmolarity in cultured rat hepatocytes. Biol Chem 380 (11): 1273-1279.

Weinshilboum RM, Otterness DM, Aksoy IA, Wood TC, Her C, Raftogianis RB (1997). Sulfation and sulfotransferases 1: sulfotransferase molecular biology: cDNAs and genes. FASEB J 11 (1): 3-14.

Westin S, Heyman RA, Martin R (2005). FXR, a therapeutic target for bile acid and lipid disorders. Mini Rev Med Chem 5 (8): 719-727.

Willson TM, Brown PJ, Sternbach DD, Henke BR (2000). The PPARs: from orphan receptors to drug discovery. J Med Chem 43 (4): 527550.

Wilson FA, Burckhardt G, Murer H, Rumrich G, Ullrich KJ (1981). Sodium-coupled taurocholate transport in the proximal convolution of the rat kidney in vivo and in vitro. J Clin Invest 67 (4): $1141-1150$

Wisely GB, Miller AB, Davis RG, Thornquest AD, Jr, Johnson R, Spitzer T et al. (2002). Hepatocyte nuclear factor 4 is a transcription factor that constitutively binds fatty acids. Structure 10 (9): 12251234.

Xie W, Radominska-Pandya A, Shi Y, Simon CM, Nelson MC, Ong ES et al. (2001). An essential role for nuclear receptors SXR/PXR in detoxification of cholestatic bile acids. Proc Natl Acad Sci USA 98 (6): 3375-3380.

Xie W, Yeuh MF, Radominska-Pandya A, Saini SP, Negishi Y, Bottroff BS et al. (2003). Control of steroid, heme, and carcinogen metabolism by nuclear pregnane $\mathrm{X}$ receptor and constitutive androstane receptor. Proc Natl Acad Sci USA 100 (7): 4150-4155.

Xie W, Uppal H, Saini SP, Mu Y, Little JM, Radominska-Pandya A et al. (2004). Orphan nuclear receptor-mediated xenobiotic regulation in drug metabolism. Drug Discov Today 9 (10): 442-449.

Yamagata K, Furuta H, Oda N, Kaisaki PJ, Menzel S, Cox NJ et al. (1996). Mutations in the hepatocyte nuclear factor-4alpha gene in maturity-onset diabetes of the young (MODY1). Nature 384 (6608): 458-460.

Yamamoto Y, Moore R, Goldsworthy TL, Negishi M, Maronpot RR (2004). The orphan nuclear receptor constitutive active/androstane receptor is essential for liver tumor promotion by phenobarbital in mice. Cancer Res 64 (20): 7197-7200.

Yang F, Huang X, Yi T, Yen Y, Moore DD, Huang W (2007). Spontaneous development of liver tumors in the absence of the bile acid receptor farnesoid X receptor. Cancer Res 67 (3): 863-867.

Yang Y, Zhang M, Eggertsen G, Chiang JY (2002). On the mechanism of bile acid inhibition of rat sterol 12alpha-hydroxylase gene (CYP8B1) transcription: roles of alpha-fetoprotein transcription factor and hepatocyte nuclear factor 4alpha. Biochim Biophys Acta 1583 (1): 63-73.

Yano K, Kato H, Morita S, Takahara O, Ishibashi H, Furukawa R (2002). Is bezafibrate histologically effective for primary biliary cirrhosis? Am J Gastroenterol 97 (4): 1075-1077.

Yerushalmi B, Sokol RJ, Narkewicz MR, Smith D, Karrer FM (1999). Use of rifampin for severe pruritus in children with chronic cholestasis. J Pediatr Gastroenterol Nutr 29 (4): 442-447.

Zelcer N, Tontonoz P (2006). Liver X receptors as integrators of metabolic and inflammatory signaling. J Clin Invest 116 (3): 607614.

Zhang J, Huang W, Qatanani M, Evans RM, Moore DD (2004a). The constitutive androstane receptor and pregnane $\mathrm{X}$ receptor function coordinately to prevent bile acid-induced hepatotoxicity. J Biol Chem 279 (47): 49517-49522.

Zhang M, Chiang JY (2001). Transcriptional regulation of the human sterol 12alpha-hydroxylase gene (CYP8B1): roles of heaptocyte nuclear factor 4 alpha in mediating bile acid repression. J Biol Chem 276 (45): 41690-41699.

Zhang Y, Castellani LW, Sinal CJ, Gonzalez FJ, Edwards PA (2004b). Peroxisome proliferator-activated receptor-gamma coactivator 1alpha (PGC-1alpha) regulates triglyceride metabolism by activation of the nuclear receptor FXR. Genes Dev 18 (2): 157-169.

Zollner G, Trauner M (2006). Molecular mechanisms of cholestasis. Wien Med Wochenschr 156 (13-14): 380-385.

Zollner G, Trauner M (2008). Mechanisms of cholestasis. Clin Liver Dis 12 (1): 1-26.

Zollner G, Fickert P, Zenz R, Fuchsbichler A, Stumptner C, Kenner L et al. (2001). Hepatobiliary transporter expression in percutaneous liver biopsies of patients with cholestatic liver diseases. Hepatology 33 (3): 633-646.

Zollner G, Fickert P, Fuchsbichler A, Silbert D, Wagner M, Arbeiter S et al. (2003a). Role of nuclear bile acid receptor, FXR, in adaptive $\mathrm{ABC}$ transporter regulation by cholic and ursodeoxycholic acid in mouse liver, kidney and intestine. J Hepatol 39 (4): 480-488.

Zollner G, Fickert P, Silbert D, Fuchsbichler A, Marschall HU, Zatloukal K et al. (2003b). Adaptive changes in hepatobiliary transporter expression in primary biliary cirrhosis. J Hepatol 38 (6): 717727.

Zollner G, Wagner M, Fickert P, Geier A, Fuchsbichler A, Silbert D et al. (2005). Role of nuclear receptors and hepatocyte-enriched transcription factors for Ntcp repression in biliary obstruction in mouse liver. Am J Physiol Gastrointest Liver Physiol 289: G798G805.

Zollner G, Fickert P, Silbert D, Fuchsbichler A, Wagner M, Guo GL et al. (2006a). Role of nuclear bile salt receptors FXR and PXR in mediating adaptive hepatobiliary transporter response to cholic acid (CA) in mouse liver [Abstract]. Gastroenterology 24: (Suppl. 1): A59.

Zollner G, Marschall HU, Wagner M, Trauner M (2006b). Role of nuclear receptors in the adaptive response to bile acids and cholestasis: pathogenetic and therapeutic considerations. Mol Pharm 3 (3): 231-251.

Zollner G, Wagner M, Moustafa T, Fickert P, Silbert D, Gumhold J et al. (2006c). Coordinated induction of bile acid detoxification and alternative elimination in mice: role of FXR-regulated organic solute transporter-\{alpha\}/beta in the adaptive response to bile acids. Am J Physiol Gastrointest Liver Physiol 290 (5): G923G932.

Zollner G, Wagner M, Fickert P, Silbert D, Gumhold J, Zatloukal K et al. (2007). Expression of bile acid synthesis and detoxification enzymes and the alternative bile acid efflux pump MRP4 in patients with primary biliary cirrhosis. Liver Int 27 (7): 920-929. 